\title{
KIRREL is differentially expressed in adipose tissue from 'fertilt' and 'fertil-' cows: in vitro role in ovary?
}

\author{
S Coyral-Castel $1,2,3,4,5$, C Ramé ${ }^{1,2,3,4}$, J Cognié ${ }^{1,2,3,4}$, J Lecardonnel ${ }^{6,7}$, S Marthey ${ }^{6,7}$, D Esquerré ${ }^{6,7}$, \\ C Hennequet-Antier ${ }^{8}$, S Elis ${ }^{1,2,3,4}$, S Fritz ${ }^{9}$, M Boussaha ${ }^{6,7}$, F Jaffrézic ${ }^{6,7}$ and J Dupont ${ }^{1,2,3,4}$ \\ ${ }^{1}$ INRA, UMR85 Physiologie de la Reproduction et des Comportements, Nouzilly, France, ${ }^{2}$ CNRS, UMR7247, \\ Nouzilly, France, ${ }^{3}$ Université François Rabelais de Tours, Tours, France, ${ }^{4}$ IFCE, Nouzilly, France, ${ }^{5}$ Département \\ GIPSIE, Institut de I'Elevage, Paris Cedex 12, France, 'INRA, UMR1313, Génétique Animale et Biologie Intégrative, \\ Jouy-en-Josas, France, ${ }^{7}$ AgroParisTech, UMR1313 Génétique Animale et Biologie Intégrative, Jouy-en-Josas, France, \\ ${ }^{8}$ INRA, UR83 Recherches Avicoles, Nouzilly, France and ${ }^{9}$ ALLICE, Paris Cedex 12, France
}

Correspondence should be addressed to J Dupont; Email: joelle.dupont@inra.fr

\begin{abstract}
We have previously shown that dairy cows carrying the 'fertil-' haplotype for one quantitative trait locus affecting female fertility located on the bovine chromosome three (QTL-F-Fert-BTA3) have a significantly lower conception rate and body weight after calving than cows carrying the 'fertil+' haplotype. Here, we compared by Tiling Array the expression of genes included in the QTL-F-FertBTA3 in 'fertil+' and 'fertil-' adipose tissue one week after calving when plasma non-esterified fatty acid concentrations were greater in 'fertil-' animals. We observed that thirty-one genes were overexpressed whereas twelve were under-expressed in 'fertil + ' as compared to 'fertil-' cows $(P<0.05)$. By quantitative PCR and immunoblot we confirmed that adipose tissue KIRREL mRNA and protein were significantly greater expressed in 'fertil +' than in 'fertil-'. KIRREL mRNA is abundant in bovine kidney, adipose tissue, pituitary, and ovary and detectable in hypothalamus and mammary gland. Its expression (mRNA and protein) is greater in kidney of 'fertil + ' than 'fertil-' cows $(P<\mathbf{0 . 0 5})$. KIRREL (mRNA and protein) is also present in the different ovarian cells with a greater expression in granulosa cells of 'fertilt' than 'fertil ${ }^{\prime}$ ' cows. In cultured granulosa cells, recombinant KIRREL halved steroid secretion in basal state $(P<0.05)$. It also decreased cell proliferation $(P<0.05)$ and in vitro oocyte maturation $(P<0.05)$. These results were associated to a rapid increase in MAPK1/3 and MAPK14 phosphorylation in granulosa cells and to a decrease in MAPK1/3 phosphorylation in oocyte. Thus, KIRREL could be a potential metabolic messenger linking body composition and fertility. Reproduction (2018) $\mathbf{1 5 5} 181-196$
\end{abstract}

\section{Introduction}

We have previously shown that primiparous cows carrying 'fertilt' haplotype for one quantitative trait locus affecting female fertility located on the bovine chromosome 3 (QTL-F-Fert-BTA3) had a greater conception rate 35 days after the first artificial insemination than those carrying 'fertil ${ }^{\prime}$ ' haplotype (Coyral-Castel et al. 2011). This QTL-F-Fert-BTA3, finely mapped (Druet et al. 2008), was described to affect early reproductive events (Guillaume et al. 2007) and explained $14 \%$ of the total genetic variance (Ben Jemaa et al. 2008).

We observed no differences in ovarian activity (number of follicles and follicular waves, length of estrus cycle) in 'fertilt' and 'fertil-' heifers and cows (CoyralCastel et al. 2011). However, we have demonstrated that the lower fertility of 'fertil-' females could be partially due to a lowest quality of the oocytes and consequently of pre-implantation embryo development (CoyralCastel et al. 2012). We have also characterized 'fertilt' and 'fertil-' cows for food intake and eating behavior, milk production, live weight and plasma metabolites during the first lactation. Interestingly, the body weight of 'fertil-' cows in the first eight weeks post partum was significantly lower than 'fertil+' cows (Coyral-Castel et al. 2013), suggesting a greater fat mobilization in 'fertil-' animals. During early lactation in cow, it is well known that energy expenditures for physiological functions, such as milk production, locomotion, maintenance or reproduction, are greater than the energy provided by feed intake. The maximum dry matter intake is reached about four to ten weeks after peak milk (Coppock 1985). Therefore, high-yielding dairy cows assume a period of negative energy balance, but its magnitude and duration are quite variable (Butler et al. 1981). As a result of the energy deficit, body reserves are mobilized (by increased lipolysis) (Bauman \& Bruce Currie 1980, Schröder \& Staufenbiel 2006) and cows may lose body weight and body condition. In early lactation, cows may mobilize 
about $50 \mathrm{~kg}$ of lipid (Bauman \& Bruce Currie 1980) to support lactation. The use of body reserves accounts energetically for about $33 \%$ of the milk produced in the first month of lactation (Bauman \& Bruce Currie 1980). Mobilization of fat results in release of non-esterified fatty acids (NEFA) in blood, which were reviewed as indicators of energy status of ruminants (Bowden 1971). It is now well established that negative energy balance impact reproductive traits at various levels of the hypothalamo-pituitary-gonadal axis (Beam \& Butler 1999, Roche et al. 2000, 2009, Leroy et al. 2008). Adipose tissue is not only an energy storage organ but it is also able to secrete a number of hormone-like compounds that regulates adipocyte development and metabolic function (Ouchi et al. 2011) but also fertility (Campos et al. 2008, Tersigni et al. 2011).

In order to better understand the molecular mechanisms involved in the lower fertility and greater fat mobilization of 'fertil-' cows, we compared by Tiling Array the expression of genes included in QTL-F-FertBTA3 in the adipose tissue of 'fertil+' and 'fertil-' females one week after calving. We then studied the distribution in bovine tissues of one candidate gene, Kin of IRRE like (Drosophila)-like (KIRREL), significantly greater expressed in 'fertilt' adipose tissue. Finally, we localized KIRREL by immunohistochemistry in bovine ovarian cells and investigated more precisely its in vitro effects on the granulosa cell steroidogenesis and proliferation and oocyte maturation by using recombinant KIRREL.

\section{Materials and methods}

\section{Ethics}

An ethics committee ('Comité d'Ethique en Expérimentation Animale $\mathrm{Val}$ de Loire (CEEA $V \mathrm{dL}^{\prime}$ ), protocol registered under ref. $n^{\circ}$ 2012-10-4) approved all experimental protocols, which were consistent with the guidelines provided by the French Council for Animal Care.

\footnotetext{
Animals

Thirty-six Holstein dairy cows $(n=18$ fertil+ and $n=18$ fertilanimals), born in 2006, were monitored during their second lactation. Dairy cows were managed in straw-bedded yards and fed ad libitum with a total mixed ration composed of $64.5 \%$ maize silage, $10 \%$ soybean, $15 \%$ concentrate, $10 \%$ dehydrated alfalfa and $0.5 \%$ calcium oxide $(\mathrm{CaO})$. After each milking, cows were automatically weighed (software RIC version RW1.7). Only the morning live body weight was used for weight analyses, because the afternoon body weight was more variable. Animals were artificially inseminated from 55 to 60 days postpartum $12 \mathrm{~h}$ after heat detection with the semen of the same bull. Blood samples were taken from the tail before diet distribution, one week after calving and 5 months of pregnancy (about 7 and 8 months after calving). Plasmas were stored at $20^{\circ} \mathrm{C}$ until assay. NEFA plasma concentrations were determined by enzymatic colorimetry on a multiparameter
}

analyzer (KONE Instruments Corporation, Espoo, Finland). Energy balance (EB, expressed in Mcal/day) was calculated one week after calving when the adipose biopsy was performed as described below. It was calculated per week according to the INRA feeding systems as the difference between the energy intake and the energy requirements for maintenance, milk production and pregnancy. According to the INRA system, the daily requirement for maintenance is $1.1 \times 0.041 \times \mathrm{kg}^{0.75}$, and the requirement for milk production is $0.44 \times$ milk production. EB is expressed in Mcal/day, where $\mathrm{kg}^{0.75}$ indicates metabolic body weight .

\section{Biopsy of subcutaneous adipose tissue}

During the second lactation, biopsies of adipose tissue were collected from the same animals at $1 \mathrm{wkpp}$ (one week postpartum) and $5 \mathrm{mpg}$ (5 months of gestation). Cows were fasted for $12 \mathrm{~h}$ before surgery. Anesthesia was induced with injections of 12-14 mg of xylazine i.v. (Rompun; Bayer AG, Leverkusen, Germany) and an injection of $200 \mathrm{mg}$ of lidocaine s.c. (Lurocaïne; Vétoquinol SA, Lure, France). Subcutaneous fat was collected from the dewlap.

\section{Bovine fertility Tiling Array design}

The $385 \mathrm{k}$ bovine fertility Tiling Array was designed in both orientations to cover the QTL-F-Fert-BTA3. The sequence containing 3,627,832 nt located from position 9,887,417 to $13,515,249$ on Bos Taurus chromosome 3 was got from full genome sequences for Bos taurus as provided by UCSC (bosTau4, Oct. 2007) The fertility Tiling Array was designed and produced by Roche NimbleGen Inc. (Madison, WI, USA). Highly repeated elements in the genome were repeat-masked. Concerning uniqueness, probes having a unique genome sequence match were selected with SSAHA (Ning et al. 2001). An isothermal format $\left(T_{\mathrm{m}}=76^{\circ} \mathrm{C}\right)$ and probe length constraint between 50 and $75 \mathrm{bp}$ were used for probe synthesis. Each probe overlapped its neighbor by about 40 bases. The arrays were manufactured by maskless array synthesis technology, and the oligonucleotides were synthesized on the arrays by photolithography (Singh-Gasson et al. 1999, Nuwaysir et al. 2002). NimbleGen synthesized the oligonucleotide probes in situ using a photo-mediated, maskless process in which the synthesis of each probe is directed by a digital light processor.

The array contained 343,162 50-75-mer oligonucleotides designed on both strands and tiled on average every eleven bases and 45,961 randomly generated probes. All information of bovine fertility Tiling Array platform has been submitted to the Gene Expression Omnibus (GEO) repository, and the accession number is GPL15186. Annotation of probes was obtained by aligning probe coordinates with annotation data from Ensembl database (release 56). The loci are classified into three types: (1) known protein-coding gene, known gene has at least one transcript with a sequence match in a sequence repository external to Ensembl for the same species. (2) Known by projection protein-coding gene, refers to genes that are homologous, based on Ensembl comparative analysis, to genes with known status in another species (usually human genes). (3) Putative protein-coding gene refers to genes where the 
Ensembl genebuild transcript and the Vega manual annotation have the same sequence, for every base pair.

\section{Tiling Array data analysis}

We developed a new model to perform Tiling Array analysis taking advantage that several probes are available per exon and per gene. The model proposed is a mixed model including a fixed exon and a random probe effects. In this study, our aim was to detect differentially expressed genes between 'fertil+' and 'fertil-' samples.

A hierarchical mixed model with an exon within gene effect and a random probe within exon effect has been considered for each gene $i(i=1, \ldots, l)$. For simplicity, the index $i$ will be omitted here as it is a gene-by-gene model:

$y_{j k r c}=\mu+a_{c}+\beta_{j}+(\alpha \beta)_{j c}+\gamma_{j k}+e_{j k r c}$

where $\alpha_{c}$ corresponds to a condition effect with two levels $\left(c=1.2\right.$ for 'fertil+' and 'fertil-'), $\beta_{j}$ corresponds to an exon effect $j$ within gene $i\left(j=1, \ldots, n_{i}\right)$ and $(\alpha \beta)_{j c}$ is the interaction term between exon and condition. Parameter $\gamma_{j k}$ corresponds to the probe effect $k$ within exon $j\left(k=1, \ldots, n_{j}\right)$. The probe effect is assumed to be a random effect such that $\gamma_{j k} \sim \mathcal{N}\left(0, \tau_{i}^{2}\right)$ , with gene-by-gene variances $\tau_{i}^{2}$. Residuals $e_{j k r c}$ are also assumed independent and normally distributed such that $e_{j k r c} \sim \mathcal{N}\left(0, \sigma_{i}^{2}\right)$, with gene-by-gene variances $\sigma_{i}^{2}$. Index $r$ represents the biological replicates $(r=1, \ldots, R)$.

In this model, testing for differenally expressed genes is equivalent to testing the null hypothesis $H_{0}: \mu_{1}=\mu_{2}$, where $\mu_{1}=\mu+\alpha_{1}$ and $\mu_{2}=\mu+\alpha_{2}$ for two conditions ( $c=1.2$ for 'fertil ${ }^{\prime}$ ' and 'fertil-'). Taking into account multiple testing, $P$ values were adjusted by Benjamini-Hochberg's procedure to control the false discovery rate (Benjamini \& Hochberg 1995). This model was applied on two datasets containing annoted probes with gene and exon information: 5822 probes matching to 62 genes and 449 exons in the analysis for the forward strand, and 4379 probes matching to 62 genes and 352 exons for the reverse strand.

Our model could also be used to detect differentially expressed exons and genes with alternative splicing. $\mathrm{R}$ functions implementing this model are available upon request from $\mathrm{F}$ Jaffrézic. We focused our study on known and known by projection protein-coding genes. Genes were classified according to the Gene Ontology using NCBI, Ensembl, DAVID and the Gene Ontology website (AmiGO release 1.8 ).

\section{Total RNA extraction}

Subcutaneous adipose tissue was sampled at the dewlap of 36 s lactation cows ( 18 'fertilt' and 18 'fertil-') one week after parturition and at 5 months of pregnancy (16 'fertilt' and 14 'fertil $-^{\prime}$ ), frozen in liquid nitrogen and stored at $-80^{\circ} \mathrm{C}$ until use. Total RNA was extracted on ice from $250 \mathrm{mg}$ of tissue with an ultraturax homogenizer using $8 \mathrm{~mL}$ of QIAzol lysis reagent (Qiagen). Chloroform $(0.2 \mathrm{~mL})$ was added to each sample. Tubes were waved for $15 \mathrm{~s}$ and left at room temperature for $5 \mathrm{~min}$ before centrifugation $\left(5000 \mathrm{~g}, 15 \mathrm{~min}, 4^{\circ} \mathrm{C}\right)$. Each aqueous phase was mixed to equal volume of ethanol $70 \%$ (v:v). Then, total RNA was purified using a RNeasy Midi Kit
(Qiagen) according to the manufacturer's recommendations. During purification, a treatment with a RNase-free DNasel (Qiagen) was performed. After elution with RNase-free water, samples were evaporated without heating during $1.5 \mathrm{~h}$ in a Thermo Savant SPD1010 SpeedVac System and stored at $-80^{\circ} \mathrm{C}$ until cDNA synthesis. RNA quantity was assessed with a NanoDrop Spectrophotometer (Nyxor Biotech, Paris, France) and RNA quality with an Agilent 2100 Bioanalyzer using a RNA 6000 Nano assay protocol (Agilent Technologies). The RNA integrity number (RIN) for each RNA sample is shown in the Supplementary Table 1 (see section on supplementary data given at the end of this article).

For RT-PCR, total RNA from bovine tissues (liver, mammary gland, heart, adipose tissue, kidney, pituitary, lung, skeletal muscle, ovary, hypothalamus, small follicles $(<6 \mathrm{~mm})$, large follicles $(>7 \mathrm{~mm})$, corpus luteum, ovarian cortex and granulosa cells) from slaughterhouse was extracted on ice with an ultraturax homogenizer in TRIzol reagent according to manufacturer's recommendation (Invitrogen by Life Technologies, Villebon sur Yvette, France). A treatment with DNasel using the DNA-free Kit (Ambion by Life Technologies) was performed on the total RNAs. Total RNA from granulosa cells in culture was extracted using $1 \mathrm{~mL}$ of TRIzol reagent by scratching wells. RNA quantity was assessed with a NanoDrop Spectrophotometer.

\section{cDNA synthesis and labeling, array hybridization, washing and scanning}

Array hybridation was performed using cDNA of adipose tissue from eighteen animals (nine 'fertil+' and nine 'fertil-') one week after calving that is a stage of intense adipose tissue mobilization. Samples were prepared, labeled and hybridized according to the NimbleGen Arrays User's Guide: Gene Expression Analysis, v3.2. cDNAs were synthesized using an Invitrogen Superscript Double-Stranded cDNA Synthesis Kit (Invitrogen by Life Technologies). They were then purified using a MinElute Reaction Cleanup Kit (Qiagen). Samples were labeled with Cy3 with a NimbleGen One-Color DNA Labeling Kit (Roche NimbleGen, Inc.). Hybridization solution was prepared from the NimbleGen Hybridization Kit (Roche NimbleGen, Inc.), and Cy3-labeled samples were hybridized on the $385 \mathrm{~K}$ array at $42^{\circ} \mathrm{C}$ for $18 \mathrm{~h}$. Finally, arrays were washed with solutions of the NimbleGen Wash Buffer Kit (Roche NimbleGen, Inc.). Arrays were scanned with a GenePix $4000 B$ Scanner at $532 \mathrm{~nm}$. Data were extracted with the Roche NimbleScan software (Roche NimbleGen, Inc.).

\section{Reverse transcription and polymerase chain reaction}

Reverse transcription (RT) of total RNA $(1 \mu \mathrm{g})$ was performed for $1 \mathrm{~h}$ at $37^{\circ} \mathrm{C}$ in a $20 \mu \mathrm{L}$ mixture as previously described (Coyral-Castel et al. 2010). Single-strand cDNAs of KIRREL and ACTR3 were amplified with specific primers (Invitrogen by Life technologies, ). PCR was carried out in a previously described mixture (Coyral-Castel et al. 2010) for 30 (ACTR3) or 40 (KIRREL) PCR cycles $\left(1 \mathrm{~min}\right.$ at $94^{\circ} \mathrm{C}, 1 \mathrm{~min}$ at $58^{\circ} \mathrm{C}, 1 \mathrm{~min}$ at $72^{\circ} \mathrm{C}$ ), with a final extension step of $7 \mathrm{~min}$ at $72^{\circ} \mathrm{C}$. PCR products were visualized in a $1.5 \%(\mathrm{w}: \mathrm{v})$ agarose gel stained 
with ethidium bromide. ACTR3 was used as positive control. Finally, DNA was extracted from the agarose gel using the EZNA microelute Gel Extraction kit (VWR, Fontenay-sous-Bois, France) according to the manufacturer's procedure. DNA was sequenced by Beckman Coulter Genomics (Grenoble, France). RT and PCR consumables were purchased from Promega.

\section{Real-time quantitative PCR (qPCR)}

Targeted cDNAs were quantified by real-time PCR using SYBR Green Supermix (Bio-Rad) and $250 \mathrm{nM}$ of specific primers (Invitrogen by Life technologies, Table 1) in total volume of $20 \mu \mathrm{L}$ in a MyiQ Cycle device (Bio-Rad). For adipose tissue, samples from thirty-six animals $(n=18$ 'fertilt' and $n=18$ 'fertil-' animals) at $1 \mathrm{wkpp}$ and thirty animals $(n=16$ 'fertil+' and $n=14$ 'fertil-' animals) at 5 months of pregnancy were tested in duplicate on the same plate and the CVs was less than 5\%. PCR amplification with water, instead of cDNA, was performed systematically as a negative control. After incubation for $2 \mathrm{~min}$ at $50^{\circ} \mathrm{C}$ and a denaturation step of $10 \mathrm{~min}$ at $95^{\circ} \mathrm{C}$, samples were subjected to 40 cycles $\left(30 \mathrm{~s}\right.$ at $95^{\circ} \mathrm{C}, 30 \mathrm{~s}$ at $60^{\circ} \mathrm{C}$, $30 \mathrm{~s}$ at $72^{\circ} \mathrm{C}$ ), followed by the acquisition of the melting curve. Primers' efficiency $(E)$ was performed from serial dilutions of a pool of obtained cDNA and ranged from 1.80 to 2.16. For normalization, the expressions of four housekeeping genes - PPIA (cyclophilin A), RPL19, ACTR3 and EEF1A1 - were examined. For each gene, expression was calculated according to primer efficiency and Cq: expression $=E^{-\mathrm{Cq}}$. These four housekeeping genes showed expressional changes between «fertil+» and «fertil-» tissues or cells. Therefore, the data were normalized to the geometric mean of PPIA and EEF1A1 (the most stable combination) following the report that suggests the geometric mean of multiple housekeeping genes as an accurate normalization factor (Vandesompele et al. 2002).

Table 1 Oligonucleotide primer sequences.

\begin{tabular}{|c|c|c|}
\hline Primer name & Primer sequence & Accession number \\
\hline \multicolumn{3}{|l|}{ KIRREL } \\
\hline Sense & 5'-GGC AAG GTG GAG TGT TTC AT-3' & \multirow[t]{2}{*}{ XM_003585822 } \\
\hline Antisense & 5'-GGC AAG GTG GAG TGT TTC AT-3' & \\
\hline \multicolumn{3}{|c|}{ (t) } \\
\hline Sense & 5'-ACG GAA CCA CAG TTT ATC ATC-3' & \multirow[t]{2}{*}{ NM_174226 } \\
\hline Antisense & 5'-GTC CCA GTC TTC AAC TAT ACC-3' & \\
\hline \multicolumn{3}{|c|}{ 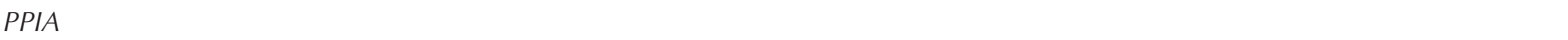 } \\
\hline Sense & 5'-GCA TAC AGG TCC TGG CAT CT-3' & \multirow[t]{2}{*}{ NM_178320 } \\
\hline Antisense & 5'-TGT CCA CAG TCA GCA ATG GT-3' & \\
\hline \multicolumn{3}{|c|}{  } \\
\hline Sense & 5'-AAT CGC CAA TGC CAA CTC-3' & \multirow[t]{2}{*}{ NM_001040516 } \\
\hline Antisense & 5'-CСС TTT CGC TTA CCT ATA CC-3' & \\
\hline \multicolumn{3}{|l|}{ EEF1A1 } \\
\hline Sense & 5'-ATC CCA GGC TGA CTG TGC TG-3' & \multirow[t]{2}{*}{ NM_174537 } \\
\hline Antisense & 5'-TGC TAC TGT GTC GGG GTT GT-3' & \\
\hline \multicolumn{3}{|c|}{ ( the } \\
\hline Sense & 5'-ATT GCT TGG GCA CTT AGA CT-3' & \multirow[t]{2}{*}{ NM_001105645 } \\
\hline Antisense & 5'-GGC ACTC AGA ATC CAA GGG T-3' & \\
\hline \multicolumn{3}{|l|}{ KCN/10 } \\
\hline Sense & 5'-CAG TCG TAG CCG CTC ACA AT-3' & \multirow[t]{2}{*}{ NM_001081601 } \\
\hline Antisense & 5'-GGT TGA GGC GGA TGT TCT CA-3' & \\
\hline \multicolumn{3}{|c|}{ ere. } \\
\hline Sense & 5'-GCT GCA GAA GAA TCC ССС TC-3' & \multirow[t]{2}{*}{ NM_001034394 } \\
\hline Antisense & 5'-TGC TGG CCA AGA CAC TAT CC-3' & \\
\hline \multicolumn{3}{|l|}{ ATP1A2 } \\
\hline Sense & 5'-CGA CAT GGA CTG ССС ТAT CC-3' & \multirow[t]{2}{*}{ NM_001081524 } \\
\hline Antisense & 5'-TTG AGG AGA GCT GAC TCG GA-3' & \\
\hline \multicolumn{3}{|l|}{ EF1A1-like } \\
\hline Sense & 5'-TCG TTG TCA TTG GGC ACG TA-3' & \multirow[t]{2}{*}{ XR_083620 } \\
\hline Antisense & 5'-TCT CTT GTT GAT CCC GCC AC-3' & \\
\hline \multicolumn{3}{|l|}{ PEA15 } \\
\hline Sense & 5'-GGA CAT CCC CAG TGA GAA GAG-3' & \multirow[t]{2}{*}{ NM_001075456 } \\
\hline Antisense & 5'-AGA TCT CAA AGA TGT GCT CGA TA-3' & \\
\hline \multicolumn{3}{|c|}{ 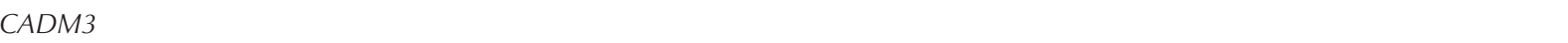 } \\
\hline Sense & 5'-AGC TCC ATG GGG AAT CTA CC-3' & \multirow[t]{2}{*}{ NM_001075946 } \\
\hline Antisense & 5'-ATG GTT CAC AGA GCA CAC GA-3' & \\
\hline \multicolumn{3}{|l|}{ IFI16 } \\
\hline Sense & 5'-AGC CAC CAA ACC TAA GGA CG-3' & \multirow[t]{2}{*}{ XM_863928 } \\
\hline Antisense & 5'-GTC CTC TGG TCA CTG CTC AC-3' & \\
\hline SLAMF6 & & \\
\hline Sense & 5'-GGA CAT TAC CGT GCC CAG AT-3' & NM_001206364 \\
\hline Antisense & 5'-CAC GTG GTG TGA TGT GCA AC-3' & \\
\hline
\end{tabular}




\section{Granulosa cell collection and primary culture}

Bovine ovaries were collected at the slaughterhouse and transported in physiological saline up to the laboratory. Granulosa cells were isolated by puncturing small follicles $(<6 \mathrm{~mm})$ in McCoy's 5A culture medium enriched with bovine serum albumin (BSA 0.1\% (w:v), Euromedex, Souffelweyersheim, France), L-glutamine (3 mM, Eurobio, Courtaboeuf, France), penicillin (100 IU/mL, PAA Laboratories, Les Mureaux, France), streptomycin $(0.1 \mathrm{mg} / \mathrm{mL}$, PAA Laboratories), Hepes (20 mM pH=7.6), bovine apo-transferrin $(5 \mu \mathrm{g} / \mathrm{mL}$, Sigma-Aldrich) and androstenedione $(0.1 \mu \mathrm{mol} / \mathrm{L}$, Sigma-Aldrich). Cells were centrifuged at $200 \mathrm{~g}$ for $5 \mathrm{~min}$, washed with fresh enriched McCoy's 5A and the pellet was resuspended in enriched McCoy's 5A supplemented with $10 \%$ (v:v) fetal bovine serum (FBS, PAA Laboratories) and amphotericin B $(5 \mu \mathrm{g} / \mathrm{mL}$, PAA Laboratories). Approximately $2 \times 10^{5}$ live cells were seeded per well of a 24 -well culture plate. After $24 \mathrm{~h}$ of culture, cells were serum starved for $18 \mathrm{~h}$ before treatment with a recombinant mouse ( $r m$ ) KIRREL (R\&D Systems), human recombinant IGF1 (Sigma) and/or ovine recombinant FSH (NIDDK, NIH). Cultures were performed at $37^{\circ} \mathrm{C}$ in a humidified air containing $5 \% \mathrm{CO}_{2}$.

\section{Cell viability}

Cell viability was determined by Blue Trypan staining. Live (normal cells) and dead cells (blue cells) were counted using a hemocytometer.

\section{Thymidine incorporation into granulosa cells}

After $18 \mathrm{~h}$ of serum starvation, culture medium was removed, and $1 \mu \mathrm{Ci} / \mathrm{mL}$ of $\left[{ }^{3} \mathrm{H}\right]$-thymidine (Perkin-Elmer) was added in the presence or absence of rm KIRREL $(10 \mathrm{ng} / \mathrm{mL}$ or $100 \mathrm{ng} / \mathrm{mL})$ in enriched McCoy's 5A. After $24 \mathrm{~h}$ of culture, excess of thymidine was removed by washing cells twice using PBS $1 \times$. Then, cells were fixed using cold 50\% (v:v) trichloroacetic acid for $10 \mathrm{~min}$ and lysed by $0.5 \mathrm{M} \mathrm{NaOH}$. The radioactivity was determined in scintillation fluid by counting in a $\beta$-photomultiplier. The values, expressed as count per min (cpm), are representative of five independent cultures with each condition in quadruplate.

\section{Progesterone and oestradiol assay}

Granulosa cells were cultured for $48 \mathrm{~h}$, after $18 \mathrm{~h}$ of serum starvation, in the presence or absence of rm KIRREL $(10 \mathrm{ng} / \mathrm{mL}$ or $100 \mathrm{ng} / \mathrm{mL})$, IGF1 $\left(10^{-8} \mathrm{M}\right)$ and/or FSH $\left(10^{-8} \mathrm{M}\right)$ in enriched McCoy's 5A. The concentration of progesterone and oestradiol in the culture medium was measured by a radioimmunoassay protocol as previously described (Tosca et al. 2005). The limit of detection of progesterone was $12 \mathrm{pg} /$ tube, and the intra- and inter-assay coefficients of variation were less than $10 \%$ and $11 \%$, respectively. The limit of detection of oestradiol was $25 \mathrm{pg} /$ tube and the intra- and inter-assay coefficients of variation were less than $12 \%$ and $10 \%$, respectively. Results were expressed as the concentration of steroids/cell protein concentration/ well. Results are presented as mean \pm S.E.M. of four independent cultures, in which each condition was analyzed in quadruplate.

\section{Protein extraction and Western blot}

Lysates of tissues (adipose tissue and kidney) or cells were prepared on ice with an ultraturax homogenizer (tissues) or by scratching wells (primary-cultured cells) in lysis buffer as previously described (Coyral-Castel et al. 2010). Proteins extracts $(80 \mu \mathrm{g})$ were denaturated, submitted to electrophoresis in a $12 \%$ (w:v) SDS-polyacrylamide gel, transferred onto nitrocellulose membrane and incubated with specific antibodies as previously described (Coyral-Castel et al. 2010). Rabbit polyclonal antibodies to AKT1, phospho-PRKAA (Thr172), PRKAA, phospho-MAPK1/3 (Tyr204/Thr202) and phospho-MAPK14 (Thr180/Tyr182) were purchased from Cell Signalling Technology (Ozyme, Saint Quantin en Yveline, France). Rabbit polyclonal antibodies to phospho-AKT1 (Ser473), MAPK1, MAPK14 and KIRREL were obtained from Santa Cruz Biotechnology (Euromedex). Mouse monoclonal antibodies to vinculin (VCL) and PCNA (proliferating cell nuclear antigen) were purchased from Sigma-Aldrich and Ozyme, respectively. Antibodies were used at 1:1000. Horseradish peroxidase-conjugated anti-rabbit and antimouse IgG were purchased from Eurobio (Les Ulis, France). Proteins were detected by enhanced chemiluminescence (Western Lightning Plus-ECL, Perkin-Elmer) using a G:Box SynGene (Ozyme) with the GeneSnap software (release 7.09.17). Signals detected were quantified with the GeneTools software (release 4.01.02). The results are expressed as the intensity signal in arbitrary units after normalization allowed by the presence of MAPK3, MAPK14, AKT1, PRKAA total (for MAPK1/3, MAPK14, AKT1 and PRKAA phosphorylation, respectively) and vinculin (for KIRREL) as an internal standard.

\section{Immunohistochemistry}

Bovine ovaries embedded in paraffin were serially sectioned at a thickness of $7 \mu \mathrm{m}$. Immunohistochemistry was performed as previously described (Tosca et al. 2005). Sections were incubated overnight with antibodies against KIRREL (1:100, Santa Cruz Biotechnology) or rabbit IgG as negative controls. Ovaries from 3 different cows were studied.

\section{Bovine oocyte collection and in vitro maturation}

Bovine ovaries were collected from a slaughterhouse in sterile $\mathrm{NaCl}$ solution and maintained at $37^{\circ} \mathrm{C}$ until aspiration. The cumulus-oocyte complexes (COCs) were aspirated from follicles 3 to $8 \mathrm{~mm}$ in diameter using an 18-gauge needle connected to a sterile test tube and to a vacuum line $(100 \mathrm{mmHg})$ as previously described (Reverchon et al. 2014). COCs were then selected under a dissecting microscope. Expanded or nonintact COCs were eliminated: only intact COCs were washed in TCM Hepes 199 (Sigma) supplemented with $0.4 \%$ BSA and gentamycine $(2.5 \mathrm{~mL} / \mathrm{L})$ under mineral oil (Sigma). The COCs were cultured in TCM 199 (Sigma) with $4 \mathrm{mg} / \mathrm{mL}$ BSA supplemented or not with different concentrations of rm KIRREL (10 and $100 \mathrm{ng} / \mathrm{mL}$ ) for $22 \mathrm{~h}$ at $39^{\circ} \mathrm{C}$ in $5 \% \mathrm{CO}_{2}$ in air with saturated humidity. Each oocyte group contained at least 50 oocytes. After maturation, COCs were denuded by pipetting with $0.5 \%$ hyaluronidase (Sigma), and the DNA was colored with Hoechst before mounting. 


\section{Statistical analysis}

All statistical analyses were conducted using the SAS software (SAS Institute INC, 2009). The MIXED procedure for linear mixed models was used to determine the changes of: (i) the live body weight, (ii) the energy balance, (iii) the plasma NEFA concentrations and (iv) adipose tissue KIRREL expression. The initial model included time after calving (1 wkpp, $5 \mathrm{mpg}$ ), haplotype (fertil+, fertil-) and time after calving $\times$ haplotype interaction.

The amount of protein content of KIRREL in adipose tissue, kidney, granulosa cells and various tissues (kidney, hypothalamus, pituitary and mammary), the KIRREL mRNA expression in various ovarian compartments and in granulosa cells, the effect of rm KIRREL on progesterone and oestradiol secretion by bovine granulosa cells in basal state or in response to IGF1 and FSH, the effect of rm KIRREL on the amount of ${ }^{3} \mathrm{H}$ thymidine incorporated into granulosa cells and on the amount of PCNA, the amount of oocyte at the GV stage and the progesterone concentration in the in vitro maturation medium and the level of phospho-MAPK $1 / 3$ in oocyte were assessed using one-way ANOVA. Numerical data are expressed as means \pm S.E.M., and results were considered statistically significant at $P<0.05$.

\section{Results}

\section{NEFA plasma concentrations, energy balance and live body weight of animals}

One week after calving, 'fertilt' cows $(n=18)$ had significant lower concentrations of plasma NEFA than 'fertil-' cows $(n=18 ; 860.6 \pm 105.4 \mu \mathrm{mol} / \mathrm{L}$ vs $1247.0 \pm 72.7 \mu \mathrm{mol} / \mathrm{L}$, respectively, $P<0.05$, Fig. $1 \mathrm{~A})$ and a greater energy balance $(-10.8 \pm 0.7 \mathrm{Mcal} /$ day vs $-14.4 \pm 0.6 \mathrm{Mcal} /$ day, respectively, $P<0.05$, Fig. $1 \mathrm{~B})$ and live body weight $(666.1 \pm 19.6 \mathrm{~kg}$ vs $610.2 \pm 0.7 \mathrm{~kg}$, respectively, $P<0.05$, Fig. $1 \mathrm{C})$, suggesting a greater adipose tissue mobilization in 'fertil-' than in 'fertil + ' cows. At 5 months of gestation (mpg) during reconstitution of body reserves, plasma NEFA, energy balance and live body weight were not significant between 'fertilt' and 'fertil-' animals ( $n=16$ 'fertilt' and $n=14$ 'fertil-') (Fig. 1).

\section{Tiling Array}

To better investigate this difference in mobilization, total adipose tissue RNA from nine 'fertilt' and nine 'fertil-' was extracted, reverse transcribed, labeled and hybridized on a $385 \mathrm{~K}$ array containing the sequence of the QTL-F-Fert-BTA3. We observed that 43 known genes were differentially expressed in adipose tissue of 'fertill' and 'fertil - ' cows $(P<0.05$, Table 2$)$. Thirtyone genes were overexpressed in 'fertilt' adipose

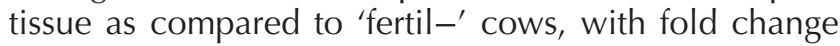
('fertil+'/'fertil-') ranging from 1.0345 to 1.6612 (Table 2). Twelve were under-expressed in 'fertil+' adipose tissue, with fold change varying from 0.7694 "fertil+" (n=18 at 1 wkpp and $n=16$ at $5 \mathrm{mpg}$ )

$\square$ "fertil-" (n=18 at 1 wkpp and $n=14$ at 5 mpg)

A
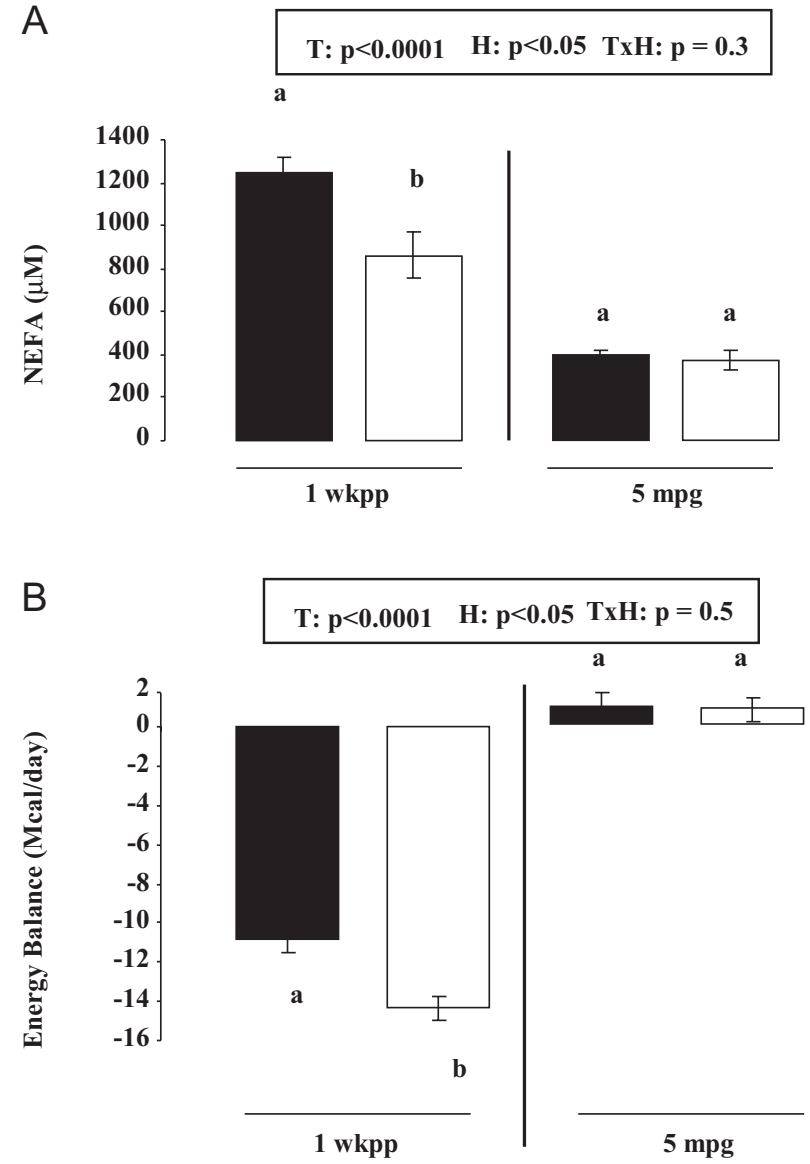

C

$$
\text { T: } p<0.05 \quad \text { H: } p<0.05 \text { TxH }: p=0.6
$$

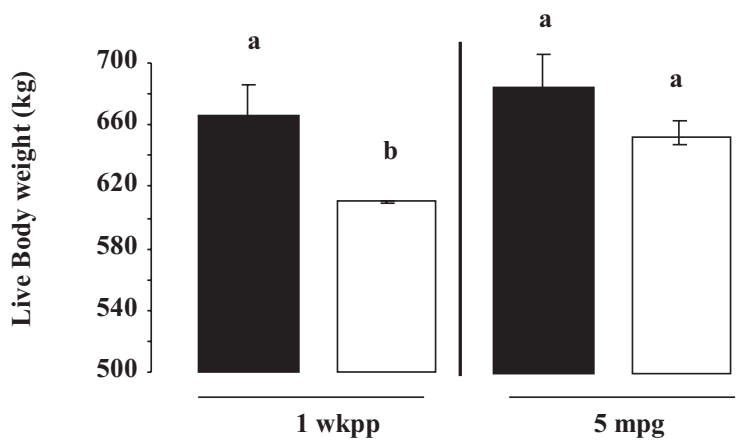

Figure 1 Plasma NEFA level (A), energy balance (EB, B), and live body weight determined on the day of sample collection (1 week postpartum ( 1 wkpp, $n=18$ fertil+ and $n=18$ fertil-) and 5 months of gestation (mpg, $n=16$ fertil+ and $n=14$ fertil-) in second lactation)). Results are presented as means \pm S.E.M. and were analyzed using the MIXED procedure for linear mixed models in the SAS software. Information about effects of the time after calving (T, 1 wkpp, $5 \mathrm{mpg}$ ), haplotype $(\mathrm{H}$, fertil+, fertil-) and time $\times$ haplotype $(\mathrm{T} \times \mathrm{H})$ interaction on live body weight, EB and plasma NEFA levels are placed above each graph. 
to 0.9714 (Table 2). Genes under-expressed in 'fertil+' adipose tissue were mainly olfactory receptors (10 on 12 genes, Table 2). We then selected about 10 genes represented in bold in Table 2 that had the highest fold change to perform expression analysis by quantitative PCR using specific primers (Table 2). Interestingly, we confirmed the results of Tiling Array by qPCR for only one gene, named KIRREL (kin of IRRE like) also known as NEPH1.
Expression of KIRREL in subcutaneous adipose tissue of 'fertil+' and 'fertil-' cows one week after calving and after five months of pregnancy

Differential adipose tissue mRNA expression of KIRREL one week after calving was confirmed in 18 'fertil-' and 18 'fertilt' animals (including the samples of nine animals per genotype used for the Tiling Array experiment). Indeed, as shown in Fig. 2A and in a good

Table 2 Genes differentially expressed between 'fertilt' and 'fertil-' adipose tissue one week after calving, with adjusted $P$-value $<0.05$.

\begin{tabular}{|c|c|c|c|}
\hline Gene symbol & Biological process & NCBI accession number & Fold change ' $\mathfrak{f}+{ }^{\prime} /{ }^{\prime} \mathbf{f}-{ }^{\prime}$ \\
\hline \multicolumn{4}{|c|}{ Cell development and organization } \\
\hline VANGL2 & Multicellular organismal development & NM_001205875 & 1.0998 \\
\hline TAGLN2 & Muscle organe development & NM_001013599 & 1.0819 \\
\hline CASQ1 & Reticulum endoplasmic organization & NM_001077877 & 1.0774 \\
\hline IGSF9 & Dendrite development & NM_001205532 & 1.0471 \\
\hline SPTA1 & Hemopoiesis & NM_001206588 & 1.0416 \\
\hline \multicolumn{4}{|c|}{ Ion and protein transport } \\
\hline COPA & Vesicle-mediated transport & NM_001105645 & 1.2486 \\
\hline KCNJ10 & Potassium ion transport & NM_001081601 & 1.1718 \\
\hline PEX19 & Protein targeting to peroxisome & NM_001034540 & 1.1232 \\
\hline \multicolumn{4}{|c|}{ Immune response } \\
\hline FCER1A & Signal transduction & NM_001100310 & 1.1468 \\
\hline$D A R C$ & Inflammatory response & NM_001015634 & 1.1439 \\
\hline$C D 1 A$ & Antigen processing and pre-immune response & NM_001102024 & 1.1261 \\
\hline LOC512286 & Antigen processing and pre-immune response & XM_003585820 & 1.1011 \\
\hline$C R P$ & Negative regulation of macrophage & NM_001144097 & 1.0970 \\
\hline SLAMF1 & Lymphocyte activation & NM_174184 & 1.0469 \\
\hline$C D 1 E$ & Antigen processing and presentation & NM_001034394 & 0.7694 \\
\hline \multicolumn{4}{|l|}{ Metabolism } \\
\hline ATP1A2 & ATP biosynthetic process & NM_001081524 & 1.2367 \\
\hline NCSTN & Membrane protein ectodomain proteolysis & NM_001034475 & 1.1652 \\
\hline PIGM & Glycosylphosphatidylinositol biosynthesis & NM_001015563 & 1.0579 \\
\hline ATP1A4 & ATP biosynthetic process & NM_001144103 & 1.0557 \\
\hline \multicolumn{4}{|c|}{ Olfactory receptors } \\
\hline LOC519294 & Signal transduction & XM_002685904 & 1.0901 \\
\hline LOC617783 & Signal transduction & XM_003581920 & 0.9664 \\
\hline LOC508806 & Signal transduction & XM_002685946 & 0.9617 \\
\hline OR10T2 & Signal transduction & XM_002685925 & 0.9572 \\
\hline OR10R2 & Signal transduction & XM_002685943 & 0.9506 \\
\hline LOC522554 & Signal transduction & XM_002685948 & 0.9456 \\
\hline OR1OK2 & Signal transduction & XM_002685942 & 0.9455 \\
\hline OR6Y1 & Signal transduction & XM_002685938 & 0.9455 \\
\hline OR6P1 & Signal transduction & XM_002685937 & 0.9449 \\
\hline LOC530601 & Signal transduction & XM_002685875 & 0.9442 \\
\hline LOC514540 & Signal transduction & XM_002685910 & 0.9377 \\
\hline \multicolumn{4}{|c|}{ Other biological process } \\
\hline EF1A1-like & Translation elongation factor activity & XR_083620 & 1.6612 \\
\hline KIRREL & Excretion & XM_003585822 & 1.2695 \\
\hline PEA15 & Anti-apoptosis & NM_001075456 & 1.2301 \\
\hline CADM 3 & Cell adhesion & NM_001075946 & 1.2057 \\
\hline APCS & Response to protein stimulus & NM_001034466 & 0.9714 \\
\hline \multicolumn{4}{|c|}{ Gene ontology unknown in Bos Taurus } \\
\hline IFI16 & Gene ontology unknown in Bos Taurus & XM_863928 & 1.3068 \\
\hline$D C A F 8$ & Gene ontology unknown in Bos Taurus & NM_001206419 & 1.1878 \\
\hline SLAMF6 & Gene ontology unknown in Bos Taurus & NM_001206364 & 1.1857 \\
\hline VSIG8 & Gene ontology unknown in Bos Taurus & NM_001205873 & 1.1660 \\
\hline IGSF8 & Gene ontology unknown in Bos Taurus & NM_001082439 & 1.1568 \\
\hline CD84 & Gene ontology unknown in Bos Taurus & XM_588136 & 1.1339 \\
\hline SLAMF8 & Gene ontology unknown in Bos Taurus & NM_001205794 & 1.0932 \\
\hline CCDC19 & Gene ontology unknown in Bos Taurus & NM_001038219 & 1.0345 \\
\hline
\end{tabular}

'f+'/'f-', 'fertil+'/'fertil-'. 
agreement with the Tiling Array results, adipose tissue KIRREL expression was significantly greater expressed in 'fertilt' than in 'fertil-' in the first week post partum $(P=0.005)$. This difference was also observed at the protein level by immunoblot (Fig. 2B, $P=0.023$ ). On the contrary, the mRNA expression of adipose tissue KIRREL was similar between the two haplotypes at 5 months of pregnancy (Fig. 2A), when animals were not in negative energy balance. Moreover, we noted that in 'fertil+' but not in 'fertil-' adipose tissue, the mRNA expression of KIRREL was significantly decreased between one week after calving and 5 months of pregnancy $(P=0.04)$.

\section{Expression of KIRREL in bovine tissues}

KIRREL (also called NEPH1) expression has been studied in human and mouse tissues, which demonstrated it to be highly expressed in kidney (Donoviel et al. 2001). However, the mRNA or protein distribution of KIRREL has never been investigated in bovine tissues. By RT-PCR, as shown in Fig. 3A, KIRREL was strongly detected in bovine adipose tissue, kidney, pituitary and ovary and less abundantly in mammary gland and hypothalamus. We then compared the expression of KIRREL mRNA by quantitative PCR in kidney, hypothalamus, pituitary and mammary gland of 'fertilt' and 'fertil-' cows slaughtered after their third or fourth lactation. As showed in Fig. 3B, kidney KIRREL mRNA expression was about two-fold greater expressed in 'fertil + ' than in 'fertil-' cows $(P<0.05)$. However, the relative expression of this gene was similar between the two haplotypes in hypothalamus, pituitary and mammary gland (Fig. 3B). By immunoblot, we confirmed at the protein level the greater expression of KIRREL in the kidney of 'fertilt' cows $(P<0.05$, Fig. 3C).

\section{Expression of KIRREL in bovine ovary}

As shown in Fig. 3A, KIRREL is expressed in bovine ovary. So, we examined more precisely its expression in the various compartments of the ovary. By RT-PCR, we showed that KIRREL mRNA was present in thecainterstitial cells from small and large follicles (SF and $\mathrm{LF})$, corpus luteum $(\mathrm{CL})$, cortex (Ctx) and granulosa cells of small and large follicles (GC SF and GC LF, Fig. 4A). By gPCR, we have observed that KIRREL was significantly greater expressed in granulosa cells from large follicles as compared to the other ovarian compartments or cells $(P<0.02$, Fig. 4B). As showed in Fig. 4C, we confirmed the presence of KIRREL protein by immunohistochemistry in the ovarian follicle. More precisely, KIRREL was localized in theca and granulosa cells, oocyte, cumulus cells and follicular fluid. We then compared the expression of KIRREL mRNA by qPCR in granulosa cells from SF of 'fertilt' and 'fertil-' cows slaughtered after their third or fourth lactation. As shown in Fig. 4D, KIRREL mRNA expression in granulosa cells
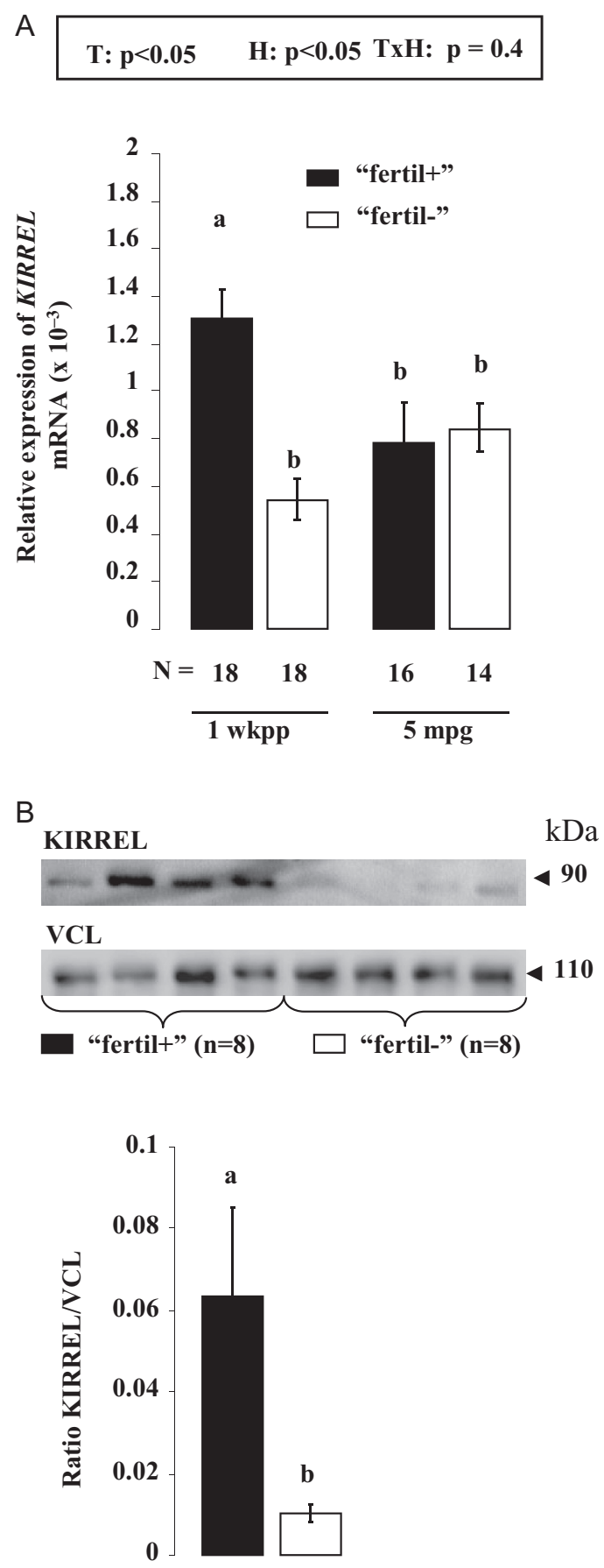

Figure 2 Relative expression of KIRREL mRNA (A) and KIRREL protein (B) in adipose tissue of 'fertilt' and 'fertil-' dairy cows. (A) mRNA of KIRREL was analyzed by RT-qPCR in adipose tissue, sampled 1 week post partum (wkpp) and at 5 months of pregnancy (mpg). The data were normalized to the geometric mean of PPIA and EEF1A1. Results are presented as means \pm S.E.M. and were analyzed using the MIXED procedure for linear mixed models in the SAS software. Information about effects of the time after calving (T, $1 \mathrm{wkpp}, 5 \mathrm{mpg}$ ), haplotype $(\mathrm{H}$, fertil+, fertil-) and time $\times$ haplotype $(\mathrm{T} \times \mathrm{H})$ are placed above the graph. (B) Protein of KIRREL was studied by Western blot in adipose tissue collected the first week post partum. VCL was used as a loading control. Results are represented as mean \pm S.E.M. Bars with different superscripts are significantly different $(P<0.05)$. 
A

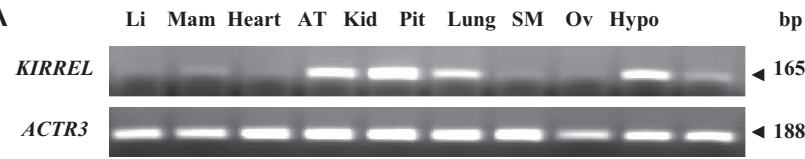

B

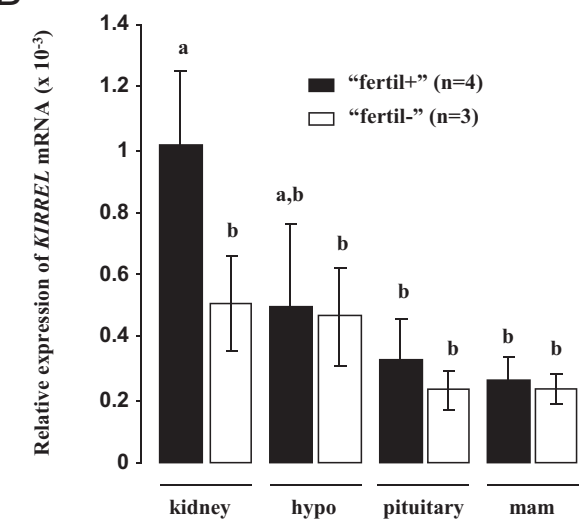

C
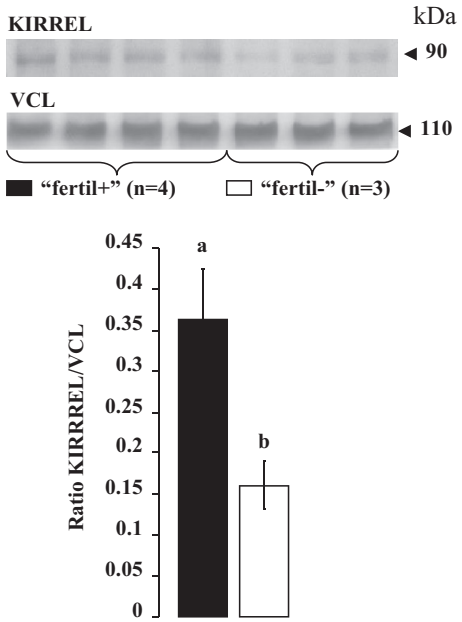

Figure 3 Expression of KIRREL mRNA in bovine tissues. (A) RT-PCR of the mRNA of KIRREL in liver (Li), mammary gland (Ma), adipose tissue (AT), kidney (Kid), pituitary (Pit), skeletal muscle (SM), ovary (Ov) and hypothalamus (Hypo). ACTR3 was used as positive control. (B) Relative expression of KIRREL mRNA in bovine kidney, hypothalamus, pituitary and mammary gland of 'fertil + ' and 'fertil - ' dairy cows. The data were normalized to the geometric mean of PPIA and EEF1A1. (C) Protein of KIRREL was studied by Western blot in kidney of 'fertil+' and 'fertil-' dairy cows. VCL was used as a loading control. Results are represented as mean \pm S.E.M. Bars with different superscripts are significantly different $(P<0.05)$.

from SF was about twelvefold greater expressed in 'fertil + ' than in 'fertil - ' cows $(P<0.002)$.

We next performed primary culture of bovine granulosa cells from SF collected from random cows and determined whether the two main hormones involved in the folliculogenesis, FSH and IGF1, were able to regulate mRNA expression of KIRREL. Treatment with FSH $\left(10^{-8} \mathrm{M}\right)$ and IGF1 $\left(10^{-8} \mathrm{M}\right)$ alone or combined for 24 or $48 \mathrm{~h}$ did not affect KIRREL expression as determined by qPCR in cultured bovine granulosa cells (data not shown).

\section{Effect of rm KIRREL on primary bovine granulosa cell steroidogenesis and proliferation}

In order to elucidate the effects of KIRREL in bovine granulosa cells, we in vitro incubated these cells with commercial recombinant mouse KIRREL (rm KIRREL) that shares more than $98 \%$ identity with bovine KIRREL. Primary bovine granulosa cells were cultured for $48 \mathrm{~h}$ in serum-free medium supplemented with either different concentrations of rm KIRREL (1, 5, 10 or $100 \mathrm{ng} / \mathrm{mL}$ ) or with or without rm KIRREL $(10 \mathrm{ng} / \mathrm{mL})$ in the presence or absence of IGF1 $\left(10^{-8} \mathrm{M}\right)$ or FSH $\left(10^{-8} \mathrm{M}\right)$. As shown in Fig. $5 \mathrm{~A}$ and $\mathrm{B}, \mathrm{rm}$ KIRREL reduced in a dose-dependent manner $(1-100 \mathrm{ng} / \mathrm{mL})$ the basal progesterone and oestradiol secretion in the culture medium $(P<0.05)$ as determined by RIA. As expected, the progesterone and oestradiol secretion was significantly increased by IGF1 and FSH (Fig. 5C and D) compared to the basal state $(P<0.01)$. However, no significant effect of $\mathrm{rm}$ KIRREL at the 10 and $100 \mathrm{ng} / \mathrm{mL}$ (data not shown) concentrations was observed on IGF1- or FSH-induced progesterone or oestradiol secretion by primary bovine granulosa cells (Fig. 5C and D). We also investigated whether rm KIRREL affected the basal proliferation of primary bovine granulosa cells. We measured the $\left[{ }^{3} \mathrm{H}\right]$-thymidine incorporation into cells after $24 \mathrm{~h}$ of culture in the presence or absence of different concentrations of $\mathrm{rm}$ KIRREL $(1,5,10$ and $100 \mathrm{ng} / \mathrm{mL})$. We observed that $\mathrm{rm}$ KIRREL significantly decreased basal proliferation of granulosa cells, in a dose-dependent manner (Fig. 6A, $P<0.04)$. These results were confirmed by evaluating the PCNA level by Western blotting (Fig. 6B). However, all these data were observed without any effects of $\mathrm{rm}$ KIRREL (10 and $100 \mathrm{ng} / \mathrm{mL}$ for $24 \mathrm{~h}$ and $48 \mathrm{~h}$ ) on the viability of primary bovine granulosa cells as determined by trypan blue incorporation (data not shown).

\section{Effect of rm KIRREL on various signaling pathways in primary bovine granulosa cells}

In the literature, KIRREL (NEPH1) has been described to modulate intracellular signaling pathways (Harita et al. 2008). Thus, we studied the effects of rm KIRREL on various signaling pathways in primary bovine granulosa cells. rm KIRREL $(100 \mathrm{ng} / \mathrm{mL})$ was added to the medium culture for different times (0-60 min), and we analyzed the protein pattern of MAPK1/3, AKT1, PRKAA and MAPK14 phosphorylation. As shown in Fig. 7A, rm KIRREL led to a significant rapid and transient increase of the MAPK1/3 phosphorylation after $5 \mathrm{~min}$ of stimulation $(P=0.0056)$. In the same way, rm KIRREL has rapidly increased MAPK14 phosphorylation from 1 to 5 min of treatment $(P<0.05$, Fig. 7B). Conversely, rm KIRREL did not affect AKT1 and PRKAA phosphorylation (data not shown). 


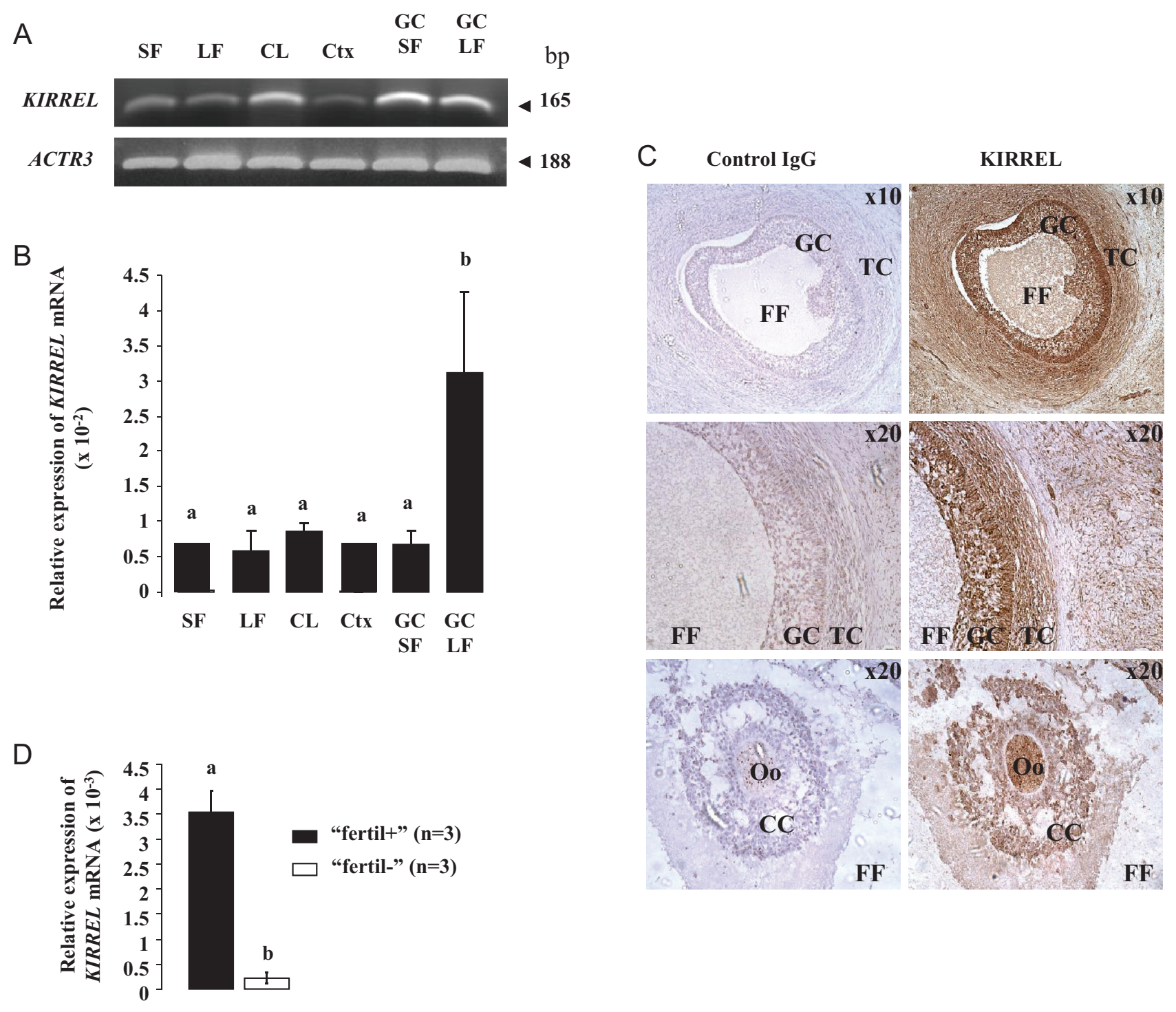

Figure 4 Expression of KIRREL mRNA (A and B) and localization (C) of KIRREL in bovine ovary. (A) RT-PCR of KIRREL mRNA in theca-interstitial cells from small follicle (SF) and large follicle (LF), CL, cortex (Ctx), granulosa cells from SF (GC SF), and granulosa cells from LF (GC LF). ACTR3 was used as a positive control. (B) Relative expression of KIRREL mRNA in the different compartments or cell types from bovine ovary. The data were normalized to the geometric mean of PPIA and EEF1A1. Results are represented as mean \pm S.E.M. $(n=6)$. Bars with different superscripts are significantly different $(P<0.05)$. (C) Localization of KIRREL by immunohistochemistry. Negative controls included a section incubated with rabbit IgG $(n=3)$. FF, follicular fluid; GC, granulosa cells; TC, theca cells; Oo, oocyte; CC, cumulus cells. (D) Relative expression of KIRREL mRNA in bovine granulosa cells from SF $(<6 \mathrm{~mm})$ of 'fertil+' and 'fertil-' dairy cows. The data were normalized to the geometric mean of PPIA and EEF1A1. Results are represented as mean \pm S.E.M.

\section{Effect of rm KIRREL on the nuclear maturation and MAPK1/3 phosphorylation of bovine oocytes in COCs and progesterone secretion by bovine COCs during in vitro maturation}

We also studied the effects of different concentrations of rm KIRREL on the meiotic progression of bovine oocytes in COCs during in vitro maturation (IVM). After $22 \mathrm{~h}$ of culture in IVM medium, about $90 \%$ of oocytes had progressed to the metaphase II stage, with less than $10 \%$ remaining at the germinal vesicle (GV) stage (Fig. 8A). Conversely, if COCs matured for $22 \mathrm{~h}$ in IVM medium supplemented with 10 or $100 \mathrm{ng} / \mathrm{mL}$ of $\mathrm{rm}$ KIRREL, $40-45 \%$ of oocytes remained at the GV stage (Fig. 8A). Thus, rm KIRREL treatment of COCs during IVM resulted in meiotic arrest. We studied the molecular mechanisms involved in the effects of rm KIRREL on the nuclear maturation of bovine oocytes in COCs by determining the MAPK3/1 phosphorylation in the presence or absence of $\mathrm{rm}$ KIRREL (10 and $100 \mathrm{ng} / \mathrm{mL}$ ) in COCs allowed to mature in vitro for $22 \mathrm{~h}$. As shown in Fig. 8B, the level of MAPK3/1 phosphorylation increased in the oocyte from COCs during IVM and the addition of $\mathrm{rm}$ 
A

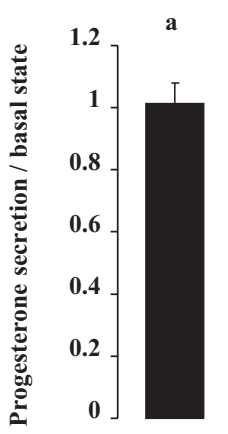

rm KIRREL ng/ml

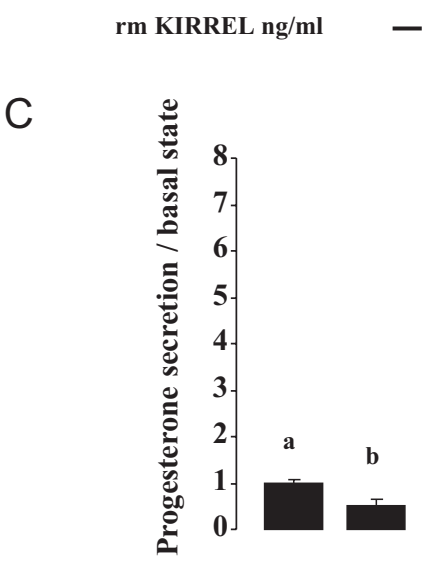

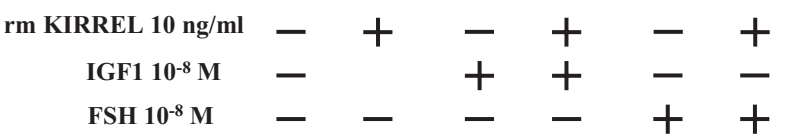

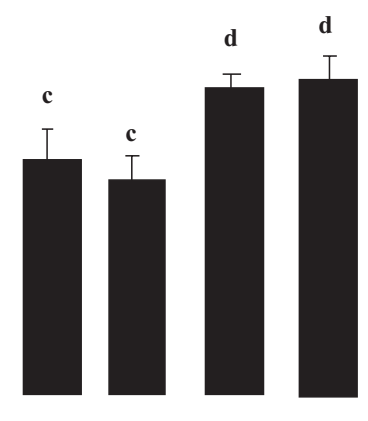

B
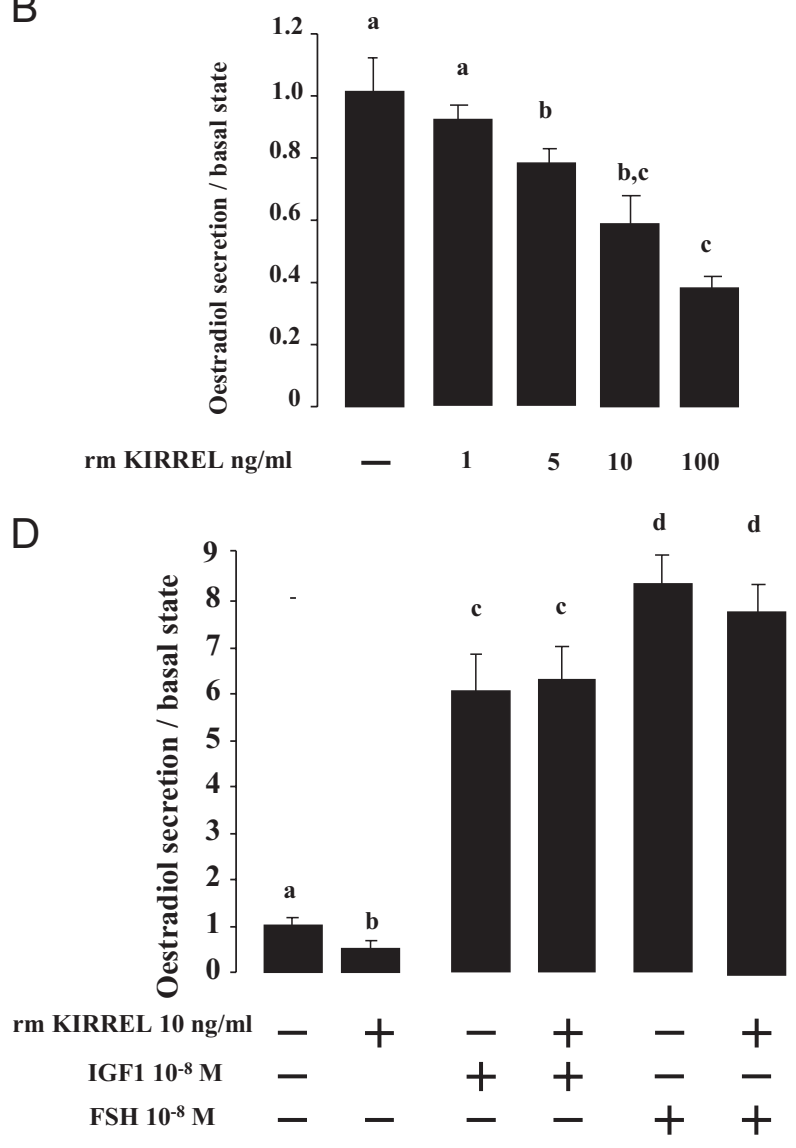

Figure 5 Effect of rm KIRREL treatment on basal and FSH- or IGF1-stimulated secretion of progesterone (A and B) and estradiol (C and D) by bovine granulosa cells. Granulosa cells from small bovine follicles were cultured for $48 \mathrm{~h}$ in a medium with serum and then in serum-free medium in the presence or in the absence of various doses of rm KIRREL (A and C) for $48 \mathrm{~h}$, or in presence or absence of $10 \mathrm{ng} / \mathrm{mL} \mathrm{rm} \mathrm{KIRREL}$, with or without $10^{-8} \mathrm{M} \mathrm{FSH}$, or $10^{-8} \mathrm{M}$ IGF1 (B and D) as described in 'Materials and methods' section. The culture medium was then collected and analyzed for progesterone (A and B) and estradiol (C and D) content by RIA. The results are expressed as the amount of steroid secreted relative to the basal state. The results are means \pm S.E.M. of six independent experiments. Bars with different letters are significantly different $(P<0.05)$.

KIRREL (10 and $100 \mathrm{ng} / \mathrm{mL}$ ) to the maturation medium for $22 \mathrm{~h}$ significantly decreased MAPK3/1 phosphorylation. We also observed that the addition of rmKIRREL to the maturation medium for $22 \mathrm{~h}$ significantly decreased progesterone secretion in COCs (Fig. 8C).

\section{Discussion}

In the present study, we reported by using Tiling Array that 'fertil-' cows, exhibiting greater plasma NEFA concentrations one week after calving, had 43 genes coding for known proteins differentially expressed in adipose tissue compared to 'fertilt' animals. More precisely, thirty-one genes were overexpressed, whereas twelve were under-expressed in 'fertilt' compared to 'fertil-' cows. We confirmed by RT-qPCR and immunoblot that KIRREL was significantly greater expressed in 'fertil+' adipose tissue compared to 'fertil - ' animals. We showed that KIRREL is mainly expressed in bovine kidney, adipose tissue, ovary and pituitary and less abundantly in hypothalamus and mammary gland. Interestingly, we observed that KIRREL mRNA expression in kidney was significantly greater expressed in 'fertil + ' compared to 'fertil-' animals. In ovary, we have shown for the first time that KIRREL was expressed in various ovarian cells including oocyte, granulosa and theca cells and its mRNA expression was significantly greater in the granulosa cells of 'fertil + ' compared to 'fertil-' cows. By using recombinant protein, we have demonstrated that KIRREL was able to decrease in vitro progesterone secretion and proliferation not only in granulosa cells but also in vitro oocyte maturation suggesting that this protein could be a potential metabolic messenger linking metabolism, body composition and fertility.

We have previously shown that Holstein cows selected for their homozygous favorable ('fertil+') haplotype at one QTL of female fertility located on the chromosome 3 (QTL-F-Fert-BTA3) had a 31\% and $26 \%$ greater success rate at 35 and 90 days after the first artificial insemination, respectively, compared to 
A

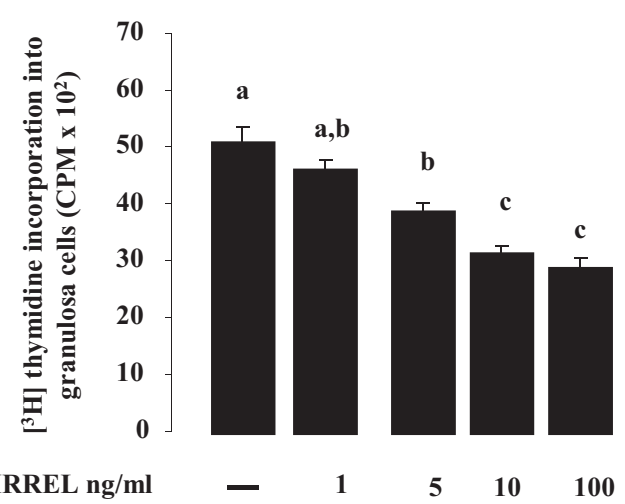

B

Blot: PCNA

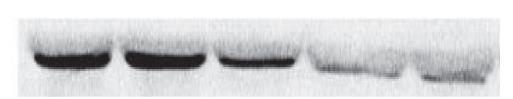

kDa

Blot: Vinculin
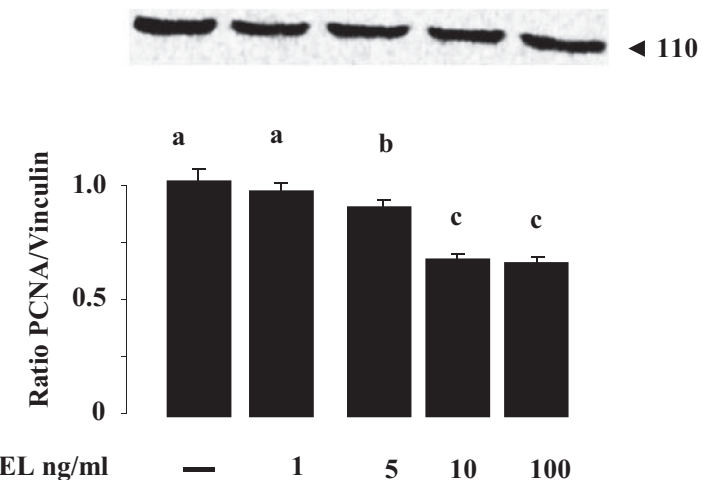

$\begin{array}{lllllll}\text { rm KIRREL ng/ml } & - & & 1 & 5 & 10 & 100\end{array}$

Figure 6 Effect of rm KIRREL on the proliferation of bovine granulosa cells. (A) Thymidine incorporation was determined in bovine granulosa cells cultured for $24 \mathrm{~h}$ in serum-free medium in the presence of different concentrations of rm KIRREL (1, 5, 10 and $100 \mathrm{ng} / \mathrm{mL}$ ) as described in 'Materials and methods' section. Results are expressed as thymidine incorporated in cpm (counts per minute). Results are representative of five independent experiments. The results are expressed as means \pm S.E.M. (B) Effect of rm KIRREL on the amount of PCNA protein in bovine granulosa cells. Protein extracts from bovine granulosa cells cultured for $48 \mathrm{~h}$ in the presence or absence of different concentrations of rm KIRREL (1, 5, 10 and $100 \mathrm{ng} / \mathrm{mL}$ ) were subjected to SDS-PAGE as described in 'Materials and methods' section. The membranes were incubated with antibodies raised against PCNA. Equal protein loading was verified by reprobing membrane with an anti-tubulin-antibody. A representative blot from three independent experiments is shown. Bars with different letters are significantly different $(P<0.05)$.

the unfavorable ('fertil-') haplotype (Coyral-Castel et al. 2011). Furthermore, we have observed slower oocyte maturation dynamics after in vivo maturation and lower blastocyst quality after in vitro embryo development in 'fertil-' compared to 'fertilt' heifers (Coyral-Castel et al. 2012). In addition to fertility problems, we have shown that 'fertil-' cows had a lower body weight in the first eight weeks after calving than 'fertil + ' cows and a more negative energy balance in the first week Reproduction (2018) 155 181-196

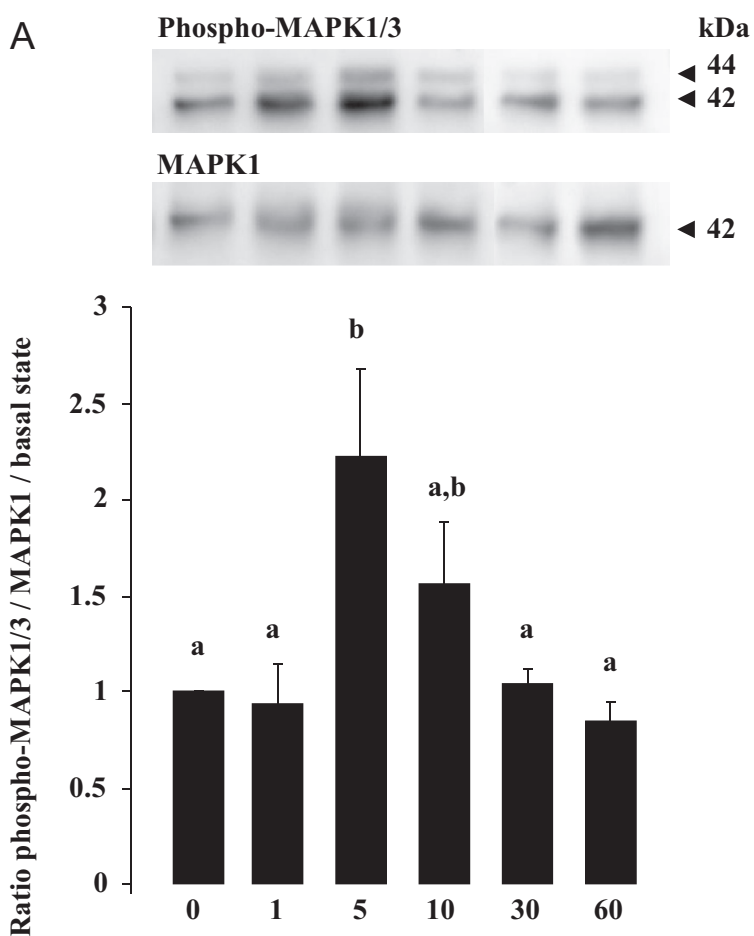

Time of rm KIRREL stimulation (minutes)
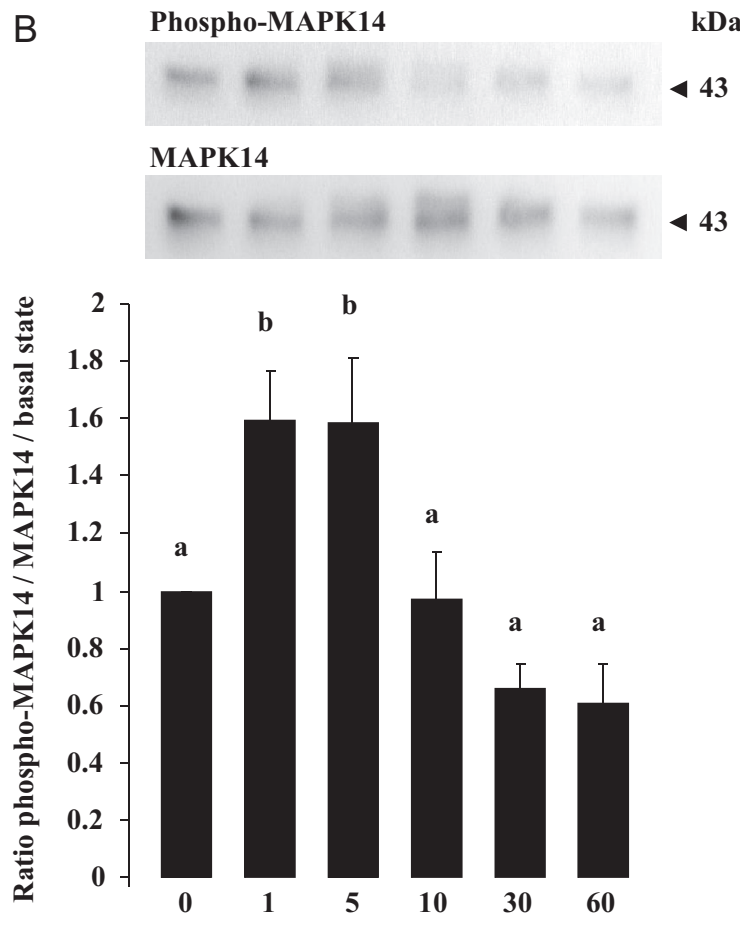

Time of rm KIRREL stimulation (minutes)

Figure 7 Effect of rm KIRREL on phosphorylation of MAPK1/3 (A) and MAPK14 (B) in primary bovine granulosa cells. After $18 \mathrm{~h}$ of serum starvation, cells were stimulated during different times $(0-60 \mathrm{~min})$ in enriched McCoy's 5A medium (without FBS) supplemented with or without rm KIRREL $(100 \mathrm{ng} / \mathrm{mL})$. Results are represented as mean \pm S.E.M. The results are representative of 4 independent cultures. Bars with different superscripts are significantly different $(P<0.05)$. 


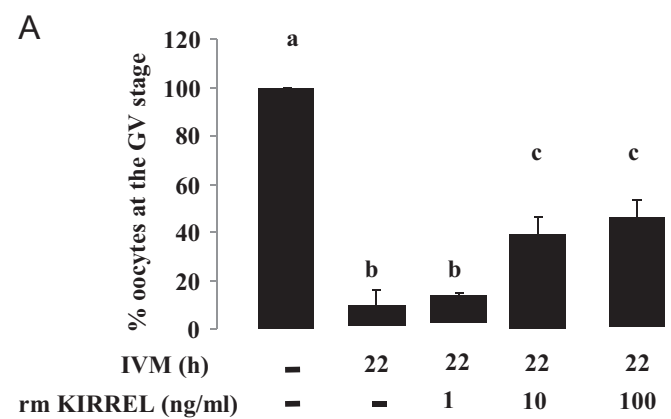

B

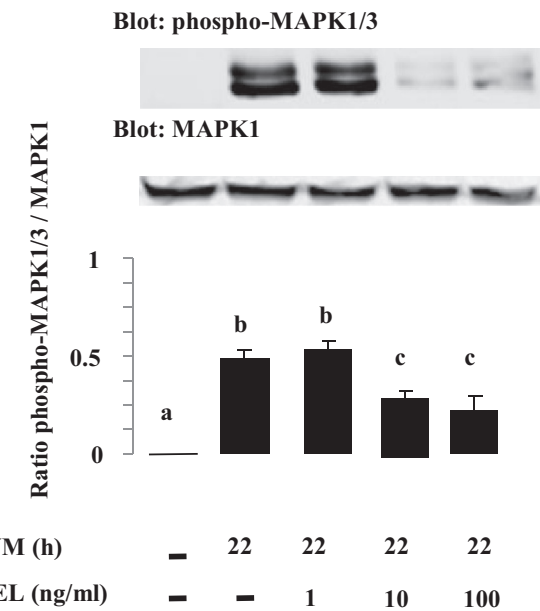

C

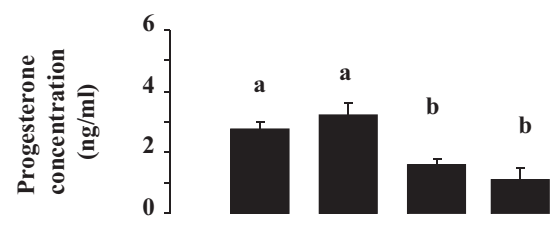

$\operatorname{rm~KIRREL~}(\mathrm{ng} / \mathrm{ml}) \quad-\quad 10 \quad 1000$

Figure 8 Effects of rm KIRREL treatment on bovine oocyte nuclear maturation. (A) Bovine oocytes were allowed to mature for $22 \mathrm{~h}$ in the presence or absence of various concentrations of rm KIRREL $(1,10$ and $100 \mathrm{ng} / \mathrm{mL}$ ). The percentage of oocytes at the GV stage in the various conditions is shown. Different letters indicate significant differences with $P<0.05$. The results are presented as mean \pm S.E.M. of three independent experiments. Fifty bovine oocytes for each set of conditions in each experiment were used. (B) Bovine COCs were cultured for $22 \mathrm{~h}$ in maturation medium in the presence or absence of rm KIRREL (1, 10 and $100 \mathrm{ng} / \mathrm{mL}$ ). COCs were then mechanically separated into oocyte and cumulus cells. Denuded oocytes (50 oocytes per lane) were lysed and subjected to Western blot analysis with antibodies against phospho-MAPK3/1 and MAPK3.

Representative blots from three independent experiments are shown. Blots were quantified, and the phosphorylated protein to total protein ratio is shown. Different letters indicate significant differences with $P<0.05$. The results are presented as means \pm S.E.M. (C) Bovine COCs were cultured for $22 \mathrm{~h}$ in maturation medium in the presence or absence of various doses of rm KIRREL (1, 10, and $100 \mathrm{ng} / \mathrm{mL}$ ). The culture medium was then collected, and its progesterone content was analyzed by RIA as described in 'Materials and methods' section. The results are expressed as $\mathrm{ng} / \mathrm{mL}$ of 50 COC-equivalent cumulus cells. The results are means \pm S.E.M. for three independent experiments. Different letters indicate significant differences with $P<0.05$. post partum, suggesting a greater fat mobilization in this haplotype (Coyral-Castel et al. 2013). In the present study, we confirmed this hypothesis since plasma NEFA concentration was significantly greater in 'fertil-' compared to 'fertilt' cows one week after calving. In order to determine if this difference in fat mobilization between the two haplotypes could contribute to explain the difference in fertility, we compared the expression of genes located in the QTL-F-Fert-BTA3 by Tiling Array in the adipose tissue of the two haplotypes. Various studies indicate that body fat content is associated with changes in reproductive performance (Randel 1990, Dunn \& Moss 1992), although the pathway which mediates such effects has not been clearly established. Some evidence suggests in vivo and in vitro that adipokines regulate the hypothalamus-pituitary-ovary axis in mammals including bovine species (Spicer et al. 1993, Williams et al. 2002, Maillard et al. 2010). In the present study, we have shown that 43 genes coding known proteins out of 124 genes on the array were differentially expressed in adipose tissue between the two haplotypes. Indeed, 31 genes were overexpressed, whereas 12 were under-expressed in 'fertilt' compared to 'fertil-' cows. However, the ratios obtained were low (less than 2) even though difference was statistically significant. One explanation of this result is that several probes were available per exon and per gene on the array. We performed qPCR on 10 genes that had the highest fold change. Unfortunately, we significantly confirmed the results of Tiling Array for only one gene, named KIRREL (kin of IRRE like) also known as NEPH1. KIRREL is significantly overexpressed in adipose tissue of 'fertilt+' compared to 'fertil-' cows one week after calving. Similar tendency was observed for two other genes (CADM3, $P=0.069$ and SLAMF6 $P=0.08$ ). These data clearly indicate that the two techniques (Tiling Array and qPCR) do not have the same sensitivity, mainly due to the design of the array.

KIRREL is a member of the nephrin-like protein family, which also includes KIRREL2 and KIRREL3. It is a molecule identified in mice by a retrovirus-mediated mutagenesis screen (Donoviel et al. 2001). KIRREL contains five extracellular immunoglobulin-like domains and is structurally related to nephrin. In human and rodents, KIRREL is abundantly expressed in the kidney but also found in some reproductive organs such as brain, placenta and testis (Donoviel et al. 2001, Beall et al. 2005). However, the presence of KIRREL in the ovary or pituitary had never been investigated. In bovine tissues, we have detected KIRREL mRNA expression in kidney, adipose tissue, ovary and pituitary and less abundantly in hypothalamus and mammary gland. Interestingly, we have shown a greater mRNA and protein expression of KIRREL in 'fertil + ' kidney compared to 'fertil-' cows. In mice, the disruption of the NEPH1 gene results in effacement of glomerular podocytes, heavy proteinuria and early postnatal death (Donoviel et al. 2001). 
Thus, KIRREL plays a pivotal role for the development and maintenance of the filtration barrier in the kidney (Donoviel et al. 2001, Neumann-Haefelin et al. 2010). In a previous work, we have observed that the plasma concentrations of urea were significantly greater in 'fertil + ' compared to 'fertil-' cows (unpublished data) suggesting that the greater KIRREL expression in the kidney of 'fertil +' could explain a better renal glomerular filtration in this haplotype. In bovine ovary, we detected KIRREL in different cells including granulosa and corpus luteum cells. As in adipose tissue one week after calving and in kidney, we have shown a greaterr expression of KIRREL in granulosa cells from 'fertilt' compared to 'fertil-' cows. The function of KIRREL in extra renal organ systems is almost unknown. Recent studies revealed that mammalian KIRREL proteins have similar cell-cell recognition functions. Furthermore, KIRREL has been shown to interact with Nephrin and Tight junction protein zona occludens-1 (ZO-1) (Huber et al. 2003, Liu et al. 2003). ZO-1 is a protein located on a cytoplasmic membrane surface of intercellular tight junctions. It interacts with the gap junction protein connexin43 (Giepmans \& Moolenaar 1998). Thus, KIRREL could be involved in the cell adhesion and in the signal transduction at cell-cell junctions. In this way, KIRREL could contribute to the greater fat mobilization in adipose cells of 'fertil-' compared to 'fertil+' cows.

In order to determine the function of KIRREL in the bovine granulosa cells, we isolated primary granulosa cells and incubated them with different concentrations of recombinant KIRREL protein. KIRREL is known to associate Nephrin and ZO-1 and these complexes are found in lipid rafts (Schwarz et al. 2001), a microdomain that consists of assemblies of sphingolipids and cholesterol in the outer leaflet of the plasma membrane. In our study, we have observed that recombinant KIRREL was able to increase rapidly MAPK $1 / 3$ and MAPK14 phosphorylation and to decrease progesterone and oestradiol secretion suggesting that rm KIRREL is active in bovine cultured granulosa cells. Recently, KIRREL has been considered as a signaling molecule. It has a cytoplasmic domain that contains a large number of tyrosine residues. These residues can be phosphorylated by a Src family tyrosine kinase, Fyn (Verma et al. 2003) that has been described in rat granulosa cells (Wayne et al. 2007). Once tyrosine is phosphorylated, KIRREL is able to modulate intracellular signaling by binding to Grb2 (Harita et al. 2008). Grb2 is a cytosolic adaptor involved in the MAPK1/3 signaling pathways. Thus, KIRREL could activate MAPK3/1 signaling pathways through the tyrosine kinase, Fyn, in bovine granulosa cells. In the present work, we have observed that recombinant KIRREL protein decreases steroid secretion. Various studies have showed that MAPK3/1 positively regulates progesterone production by granulosa cells in different species (Gyles et al. 2001, Tosca et al. 2005, 2007). Thus, it is likely that the inhibitory effect of KIRREL on the progesterone secretion is not mediated by MAPK3/1 in cultured bovine granulosa cells. The involvement of MAPK14 remains to be determined. This pathway has been described to be involved in the differential regulation of steroidogenesis in rat granulosa cells (Yu et al. 2005). In the present study, we have also shown that $\mathrm{rm}$ KIRREL decreases in vitro bovine oocyte maturation probably through an inhibition of progesterone secrection by COCs. We observed that KIRREL mRNA expression is greater in vivo in granulosa cells of 'fertil +' compared to 'fertil-' cows, but we showed that recombinant KIRREL decreases in vitro steroid production in bovine granulosa cells and oocyte maturation. So, KIRREL might not explain the better fertility in 'fertil + ' as compared to 'fertil - ' animals through its effects on the granulosa cells or oocyte. We have previously shown that progesterone secretion by cultured granulosa cells in basal state or in response to FSH or IGF1 was similar between 'fertil + ' and 'fertil-' heifers submitted to ovarian stimulation (Coyral-Castel et al. 2012). Thus, it will be interesting to know the role of KIRREL in vivo in ovarian functions in the bovine species.

In conclusion, we have shown that dairy cows selected for one QTL-F-Fert-BTA3, exhibiting difference in fertility, also had a difference in fat mobilization one week after calving and a differential expression of adipose tissue genes located in the QTL as determined by Tiling Array. Among these genes differentially expressed by Tiling Array, we confirmed the results at both mRNA and protein level for one gene named KIRREL. This gene highly is expressed in granulosa cells and could be involved in the interactions between metabolism and reproduction and could explain some infertilities in dairy cows.

\section{Supplementary data}

This is linked to the online version of the paper at https://doi.org/10.1530/REP-17-0649.

\section{Declaration of interest}

The authors declare that there is no conflict of interest that could be perceived as prejudicing the impartiality of the research reported.

\section{Funding}

This work was supported by ANR Genanimal and Apis-Gene. $\mathrm{S}$ Coyral-Castel is a PhD student supported by the 'Institut de I'Elevage' and the 'Association Nationale de la Recherche et de la Technologie'. 


\section{Acknowledgements}

The authors thank Eric Briant, Mickael Dupont, Mickael Delanoue, Ludovic Métivier and Christophe Mouaze of the Experimental Unit UEPAO for animal management and their involvement in the experiment. They also acknowledge André Eggen for his implication in the initiation of the Tiling Array protocol. The research leading to these results has received funding from ANR (Agence Nationale de la Recherche) Fertilité 1 et 2 and from Apisgene (Valoprot proposal).

\section{References}

Bauman DE \& Bruce Currie W 1980 Partitioning of nutrients during pregnancy and lactation: a review of mechanisms involving homeostasis and homeorhesis. Journal of Dairy Science 63 1514-1529. (https://doi. org/10.3168/jds.S0022-0302(80)83111-0)

Beall MH, Amidi F, Gayle DA, Wang SB, Beloosesky R \& Ross MG 2005 Placental and fetal membrane nephrin and neph1 gene expression: response to inflammation. Journal of the Society for Gynecologic Investigation 12 298-302. (https://doi.org/10.1016/j.jsgi.2005.02.009)

Beam SW \& Butler WR 1999 Effects of energy balance on follicular development and first ovulation in postpartum dairy cows. Journal of Reproduction and Fertility Supplement 54 411-424.

Ben Jemaa S, Fritz S, Guillaume F, Druet T, Denis C, Eggen A \& Gautier M 2008 Detection of quantitative trait loci affecting non-return rate in French dairy cattle. Journal of Animal Breeding and Genetics 125 280-288. (https://doi.org/10.1111/j.1439-0388.2008.00744.x)

Benjamini Y \& Hochberg Y 1995 Controlling the false discovery rate - a practical and powerful approach to multiple testing. Journal of the Royal Statistical Society Series B: Methodological 57 289-300.

Bowden DM 1971 Non-esterified fatty acids and ketone bodies in blood as indicators of nutritional status in ruminants: a review. Canadian Journal of Animal Science 51 1-13. (https://doi.org/10.4141/cjas71-001)

Butler WR, Everett RW \& Coppock CE 1981 The relationships between energy balance, milk production and ovulation in postpartum holstein cows. Journal of Animal Science 53 742-748. (https://doi.org/10.2527/ jas1981.533742x)

Campos DB, Palin MF, Bordignon V \& Murphy BD 2008 The 'beneficial' adipokines in reproduction and fertility. International Journal of Obesity 32 223-231. (https://doi.org/10.1038/sj.ijo.0803719)

Coppock CE 1985 Energy nutrition and metabolism of the lactating dairy cow. Journal of Dairy Science 68 3403-3410. (https://doi.org/10.3168/ jds.s0022-0302(85)81253-4)

Coyral-Castel S, Rame C, Fatet A \& Dupont J 2010 Effects of unsaturated fatty acids on progesterone secretion and selected protein kinases in goat granulosa cells. Domestic Animal Endocrinology 38 272-283. (https:// doi.org/10.1016/j.domaniend.2009.12.002)

Coyral-Castel S, Ramé C, Monniaux D, Fréret S, Fabre-Nys C, Fritz S, Monget P, Dupont F \& Dupont J 2011 Ovarian parameters and fertility of dairy cows selected for one QTL located on BTA3. Theriogenology 75 1239-1250. (https://doi.org/10.1016/j.theriogenology.2010.11.037)

Coyral-Castel S, Brisard D, Touze JL, Dupont M, Ramé C, Uzbekova S \& Dupont J 2012 Analysis of in vivo oocyte maturation, in vitro embryo development and gene expression in cumulus cells of dairy cows and heifers selected for one fertility QTL located on BTA3 Theriogenology 77 1822-1833. (https://doi.org/10.1016/j.theriogenology.2011.12.028)

Coyral-Castel S, Faverdin P, Ramé C, Fréret S, Guillaume D, Fritz S \& Dupont J 2013 Significant differences in fertility between dairy cows selected for one QTL located on bovine chromosome 3 are not attributable to energy balance, although eating behaviour is affected Animal 7 610-617. (https://doi.org/10.1017/S1751731112002133)

Donoviel DB, Freed DD, Vogel H, Potter DG, Hawkins E, Barrish JP, Mathur BN, Turner CA, Geske R, Montgomery CA et al. 2001 Proteinuria and perinatal lethality in mice lacking NEPH1, a novel protein with homology to NEPHRIN. Molecular and Cellular Biology 21 4829-4836. (https://doi.org/10.1128/MCB.21.14.4829-4836.2001)

Druet T, Fritz S, Boussaha M, Ben-Jemaa S, Guillaume F, Derbala D, Zelenika D, Lechner D, Charon C, Boichard D et al. 2008 Fine mapping of quantitative trait loci affecting female fertility in dairy cattle on BTA03 using a dense single-nucleotide polymorphism map. Genetics 178 2227-2235. (https://doi.org/10.1534/genetics.107.085035)

Dunn TG \& Moss GE 1992 Effects of nutrient deficiencies and excesses on reproductive efficiency of livestock. Journal of Animal Science $\mathbf{7 0}$ 1580-1593. (https://doi.org/10.2527/1992.7051580x)

Giepmans BNG \& Moolenaar WH 1998 The gap junction protein connexin43 interacts with the second PDZ domain of the zona occludens-1 protein. Current Biology 8 931-934. (https://doi. org/10.1016/S0960-9822(07)00375-2)

Guillaume F, Gautier M, Ben Jemaa S, Fritz S, Eggen A, Boichard D \& Druet T 2007 Refinement of two female fertility QTL using alternative phenotypes in French Holstein dairy cattle. Animal Genetics 38 72-74. (https://doi.org/10.1111/j.1365-2052.2006.01542.x)

Gyles SnL, Burns CJ, Whitehouse BJ, Sugden D, Marsh PJ, Persaud SJ \& Jones PM 2001 ERKs regulate cyclic AMP-induced steroid synthesis through transcription of the Steroidogenic Acute Regulatory (StAR) gene. Journal of Biological Chemistry 276 34888-34895. (https://doi. org/10.1074/jbc.M102063200)

Harita Y, Kurihara H, Kosako H, Tezuka T, Sekine T, Igarashi T \& Hattori S 2008 Neph1, a component of the kidney slit diaphragm, is tyrosinephosphorylated by the Src family tyrosine kinase and modulates intracellular signaling by binding to Grb2. Journal of Biological Chemistry 283 9177-9186. (https://doi.org/10.1074/jbc.M707247200)

Huber TB, Schmidts M, Gerke P, Schermer B, Zahn A, Hartleben Br, Sellin L, Walz G \& Benzing T 2003 The carboxyl terminus of Neph family members binds to the PDZ domain protein zonula occludens-1. Journal of Biological Chemistry 278 13417-13421. (https://doi.org/10.1074/jbc. C200678200)

Leroy J, Vanholder T, Van Knegsel ATM, Garcia-Ispierto I \& Bols PEJ 2008 Nutrient prioritization in dairy cows early postpartum: mismatch between metabolism and fertility? Reproduction in Domestic Animals 43 96-103. (https://doi.org/10.1111/j.1439-0531.2008.01148.x)

Liu G, Kaw B, Kurfis J, Rahamanuddin S, Kanwar YS \& Chugh SS 2003 Neph1 and nephrin interaction in the slit diaphragm is an important determinant of glomerular permeability. Journal of Clinical Ingestigation 112 209-221. (https://doi.org/10.1172/JCI200318242)

Maillard V, Uzbekova S, Guignot F, Perreau C, Rame C, CoyralCastel S \& Dupont J 2010 Effect of adiponectin on bovine granulosa cell steroidogenesis, oocyte maturation and embryo development. Reproductive Biology and Endocrinology 8 23. (https://doi. org/10.1186/1477-7827-8-23)

Neumann-Haefelin E, Kramer-Zucker A, Slanchev K, Hartleben B, Noutsou F, Martin K, Wanner N, Ritter A, Gödel M, Pagel P et al. 2010 A model organism approach: defining the role of Neph proteins as regulators of neuron and kidney morphogenesis. Human Molecular Genetics 19 2347-2359. (https://doi.org/10.1093/hmg/ ddq108)

Ning Z, Cox AJ \& Mullikin JC 2001 SSAHA: a fast search method for large DNA databases. Genome Research 11 1725-1729. (https://doi. org/10.1101/gr.194201)

Nuwaysir EF, Huang W, Albert TJ, Singh J, Nuwaysir K, Pitas A, Richmond T, Gorski T, Berg JP, Ballin J et al. 2002 Gene expression analysis using oligonucleotide arrays produced by maskless photolithography. Genome Research 12 1749-1755. (https://doi.org/10.1101/gr.362402)

Ouchi N, Parker JL, Lugus JJ \& Walsh K 2011 Adipokines in inflammation and metabolic disease. Nature Reviews Immunology 11 85-97. (https://doi.org/10.1038/nri2921)

Randel RD 1990 Nutrition and postpartum rebreeding in cattle. Journal of Animal Science 68 853-862. (https://doi.org/10.2527/1990.683853x)

Reverchon M, Bertoldo MJ, Ramé C, Froment P \& Dupont J 2014 CHEMERIN (RARRES2) decreases in vitro granulosa cell steroidogenesis and blocks oocyte meiotic progression in bovine species. Biology of Reproduction 90 1-15. (https://doi.org/ 10.1095/biolreprod.113.117044)

Roche JF, Mackey D \& Diskin MD 2000 Reproductive management of postpartum cows. Animal Reproduction Science 60-61 703-712. (https://doi.org/10.1016/S0378-4320(00)00107-X)

Roche JR, Friggens NC, Kay JK, Fisher MW, Stafford KJ \& Berry DP 2009 Invited review: body condition score and its association with dairy cow productivity, health, and welfare. Journal of Dairy Science 92 5769-5801. (https://doi.org/10.3168/jds.2009-2431)

Schröder UJ \& Staufenbiel R 2006 Invited review: methods to determine body fat reserves in the dairy cow with special regard to ultrasonographic 
measurement of backfat thickness. Journal of Dairy Science 89 1-14. (https://doi.org/10.3168/jds.s0022-0302(06)72064-1)

Schwarz K, Simons M, Reiser J, Saleem MA, Faul C, Kriz W, Shaw AS, Holzman LB \& Mundel P 2001 Podocin, a raft-associated component of the glomerular slit diaphragm, interacts with CD2AP and nephrin. Journal of Clinical Investigation 108 1621-1629. (https://doi.org/10.1172/ JCl200112849)

Singh-Gasson S, Green RD, Yue Y, Nelson C, Blattner F, Sussman MR \& Cerrina F 1999 Maskless fabrication of light-directed oligonucleotide microarrays using a digital micromirror array. Nature Biotechnology 17 974-978. (https://doi.org/10.1038/13664)

Spicer LJ, Alpizar E \& Echternkamp SE 1993 Effects of insulin, insulinlike growth factor I, and gonadotropins on bovine granulosa cell proliferation, progesterone production, estradiol production, and(or) insulin-like growth factor I production in vitro. Journal of Animal Science 71 1232-1241. (https://doi.org/10.2527/1993.7151232x)

Tersigni C, Di Nicuolo F, D'Ippolito S, Veglia M, Castellucci M \& Di Simone N 2011 Adipokines: new emerging roles in fertility and reproduction. Obstetrical and Gynecological Survey 66 47-63. (https:// doi.org/10.1097/OGX.1090b1013e318217b318210a318214)

Tosca L, Froment P, Solnais P, Ferre P, Foufelle F \& Dupont J 2005 Adenosine 5 '-monophosphate-activated protein kinase regulates progesterone secretion in rat granulosa cells. Endocrinology 146 4500-4513. (https://doi.org/10.1210/en.2005-0301)

Tosca L, Chabrolle C, Uzbekova S \& Dupont J 2007 Effects of metformin on bovine granulosa cells steroidogenesis: possible involvement of adenosine 5'-monophosphate-activated protein kinase (AMPK). Biology of Reproduction 76 368-378. (https://doi.org/10.1095/ biolreprod.106.055749)
Verma R, Wharram B, Kovari I, Kunkel R, Nihalani D, Wary KK, Wiggins RC, Killen P \& Holzman LB 2003 Fyn binds to and phosphorylates the kidney slit diaphragm component nephrin. Journal of Biological Chemistry $\mathbf{2 7 8}$ 20716-20723. (https://doi.org/10.1074/jbc.M301689200)

Vandesompele J, De Preter K, Pattyn F, Poppe B, Van Roy N, De Paepe A \& Speleman F 2002 Accurate normalization of real-time quantitative RT-PCR data by geometric averaging of multiple internal control genes. Genome Biology 18 RESEARCH0034.

Wayne CM, Fan H-Y, Cheng X \& Richards JS 2007 Follicle-stimulating hormone induces multiple signaling cascades: evidence that activation of Rous sarcoma oncogene, RAS, and the epidermal growth factor receptor are critical for granulosa cell differentiation. Molecular Endocrinology 21 1940-1957. (https://doi.org/10.1210/me.2007-0020)

Williams GL, Amstalden M, Garcia MR, Stanko RL, Nizielski SE, Morrison CD \& Keisler DH 2002 Leptin and its role in the central regulation of reproduction in cattle. Domestic Animal Endocrinology 23 339-349. (https://doi.org/10.1016/S0739-7240(02)00169-8)

Yu F-Q, Han C-S, Yang W, Jin X, Hu Z-Y \& Liu Y-X 2005 Activation of the p38 MAPK pathway by follicle-stimulating hormone regulates steroidogenesis in granulosa cells differentially. Journal of Endocrinology 186 85-96. (https://doi.org/10.1677/joe.1.05955)

Received 21 April 2017

First decision 15 May 2017

Revised manuscript received 18 November 2017

Accepted 23 November 2017 